\title{
Pelvic Floor Dysfunction in Nulliparous Women
}

\section{Jwan Al-Mukhtar Othman}

Department of Obstetrics \& Gynecology

Institute of Clinical Sciences, Sahlgrenska Academy

University of Gothenburg

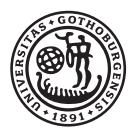

UNIVERSITY OF GOTHENBURG

Gothenburg 2022 
Cover illustration: Ida Björs

Pelvic Floor Dysfunction in Nulliparous women (C) Jwan Al-Mukhtar Othman 2022

Jwan.othman@vgregion.se

ISBN 978-91-8009-586-0 (PRINT)

ISBN 978-91-8009-587-7 (PDF)

Printed in Borås, Sweden 2022

Printed by Stema Specialtryck 
"Real change, enduring change, happens one step at a time." Ruth Bader Ginsburg 
4 Pelvic Floor Dysfunction in Nulliparous Women 


\title{
SAHLGRENSKA ACADEMY, INSTITUTE OF CLINICAL SCIENCES
}

\section{Pelvic floor dysfunction in nulliparous women Jwan Al-Mukhtar Othman}

Department of Obstetrics and Gynecology, Institute of Clinical Sciences, Sahlgrenska Academy, Gothenburg University, Gothenburg, Sweden, 2021

\begin{abstract}
Background: Pelvic floor dysfunction (PFD) is a public health problem affecting millions of women worldwide. In addition to personal suffering, it also creates an economic burden for health care systems and society. Parity and mode of delivery are well known risk factors for PFDs. Therefore, examining the prevalence of PFDs in women not exposed to childbirth provides insight into the natural history of the condition without the confounding effect of obstetric injury.
\end{abstract}

Aim: To obtain a detailed description of the age-related prevalence and predictors of PFDs in a large, national, randomly selected cohort of nulliparous women aged 25 to 64 years. This knowledge is necessary for comparisons with parous women to demonstrate the effect of pregnancy and the effect of vaginal delivery on future PFD.

Material and methods: This was a national cohort study where the study population was drawn from the Total Population Register by Statistics Sweden. The final study population consisted of 9,197 women registered in Sweden, with no births aged 25 and 64 years. Selfreported information regarding possible PFD was obtained via the web and by mail in 2014 using a 40 -item questionnaire.

\section{Results:}

Paper I: Urinary function in nulliparous women deteriorated during the four most active decades of adult life. However, $75 \%$ remained continent by age 65 . In women with a normal BMI this applied to $>80 \%$. Almost all aspects of urinary dysfunction increased with age. The most significant increase was observed for nocturia $\geq 2$, mixed urinary incontinence (MUI), leakage $\geq 1$ week, leakage of more than a few drops of urine, and bothersome UI.

Paper II: Symptoms indicating pelvic organ prolapse (sPOP) were experienced in all ages but surgical procedures for POP were rare. Bothersome sPOP was more prevalent in older women. The symptom of "bulging" was strongly associated with other irritative conditions from the genital area. These co-occurring symptoms increased with increasing frequency of "bulging".

Paper III: In nulliparous women with a history of childhood nocturnal enuresis (CNE), all the studied parameters of lower urinary tract symptoms and PFD were approximately doubled and acted as a strong marker for later PFDs.

Paper IV: The predominant component of leakage in nullipara with faecal incontinence (FI) was liquid stool, which occurred in $>90 \%$. Solid stool leakage was rare. The pattern of distribution of different types of leakage was similar in all age groups. BMI and age were interacting risk factors for FI.

Conclusion: Over a 40-year period from age 25, the prevalence of all UI parameters increased in nulliparous women. Bothersome prolapse symptoms were rare in women who have not undergone childbirth. The strongest risk factor for fecal incontinence was abnormal stool consistency. Age, BMI and CNE were important risk factors for almost all PFDs.

Keywords: Childhood nocturnal enuresis, fecal incontinence, nulliparous women, pelvic floor disorder, pelvic floor dysfunction, pelvic organ prolapse, urinary incontinence. 


\section{Swedish summary - Svensk sammanfattning}

\section{Bakgrund}

Störningar i bäckenbottens funktion hos kvinnor innefattar flera kliniska tillstånd, varav de vanligaste är urinläckage, framfall och avföringsläckage. De skapar sammantaget ett stort folkhälsoproblem som drabbar miljontals kvinnor runtom i världen, och dess effekter sträcker sig bortom de rent fysiska manifestationerna genom att de har en negativ effekt på självkänsla, sexualitet, kroppsuppfattning och livskvalitet för kvinnor i alla åldrar. Livstidsrisken för kvinnor i västvärlden att drabbas av bäckenbottenstörningar är 25\% och var femte blir opererade för urinläckage eller prolaps före 80-85 års ålder. Av medelålders svenska kvinnor har $46 \%$ minst ett symtom på bäckenbottenstörning och $15 \%$ två eller fler. Nästan varannan kvinna rapporterar urinläckage med eller utan prolapsbesvär 20 år efter en vaginal förlossning.

På grund av de ibland otillfredsställande långsiktiga resultaten av behandlingen av bäckenbottenstörningar bör förebyggande strategier och åtgärder identifieras. Antalet födslar, förlossningssätt och förlossningsrelaterade skador är kända riskfaktorer. Kunskapen om hur graviditeten i sig påverkar bäckenbotten senare i livet är däremot mycket begränsad. Kunskapen om bäckenbottenbesvär hos kvinnor som inte fött barn är begränsad och informationen i litteraturen är mycket knapphändig och fragmenterad. Att kartlägga förekomsten av bäckenbottenstörningar hos kvinnor som inte genomgått vare sig en graviditet eller en förlossning är ovärderlig för att förstå störningarnas naturliga förlopp. Sådan kunskap gör det möjligt att studera alla riskfaktorer som inte har något samband med graviditet och förlossning. 
SWEPOP-O (The Swedish Pregnancy, Obesity and Pelvic floor project on nulliparous women) syftar till att besvara några av dessa ännu obesvarade frågor. Genom att jämföra förekomsten av bäckenbottenstörning hos kvinnor som inte fött barn med de kvinnor som har fött ett barn med kejsarsnitt kan den relativa effekten av själva graviditeten på bäckenbotten uppskattas. Syftet med denna studie var att kartlägga förekomsten av urin- och tarmläckage och framfall hos en stor grupp kvinnor mellan 25-64 år som inte är gravida och som inte fött barn.

\section{Metod}

Studien är utformad som en nationell studie. Med hjälp av uppgifter inhämtade från det Totala Populationsregistret (TPR), som administreras av Statistiska Centralbyrån (SCB), gjordes ett slumpmässigt urval av icke-gravida kvinnor som inte fött barn och som var i åldrarna 25 till 64 år och var folkbokförda i Sverige. Dessa kvinnor kontaktades under våren 2014 av SCB med ett brev i vilket de ombads delta i en studie om bäckenbottenbesvär. 52\% av kvinnorna svarade via ett brev, alternativt via en internetenkät. Enkäten innehöll 40 frågor om bäckenbottenbesvär, dess svårighetsgrad och hur de eventuellt påverkade kvinnorna psykiskt och i vardagen. Den slutliga studiepopulationen uppgick till 9,197 kvinnor.

\section{Resultat}

Förekomsten av urinläckage, svårare former av läckage och olika typer av urinläckage (ansträngnings-, trängnings- och blandläckage) hos kvinnor som aldrig fött barn ökade med stigande åldern och kroppsvikt, mätt som BMI. Nästan varannan kvinna, som inte hade fött barn i åldrarna 55-64 år, med ett BMI över 35, hade urinläckage. Framfall är sällsynta hos kvinnor som inte fött barn. I vår studie fann vi att de yngsta kvinnorna rapporterade en hög 
frekvens av symtom på framfall (prolaps), vilken minskade med stigande åldern. Detta ansåg vi kunna bero på att de yngre kvinnorna hade andra likartade symtom från bäckenbotten som "buktning" och "skav" i underlivet, vilket de kunde ha misstolkat som kommande från ett framfall.

I en delstudie analyserades om sängvätning i barndomen utgör en riskfaktor för bäckenbottenbesvär i vuxen ålder. Tidigare har man funnit ett samband till enstaka bäckenbottenbesvär, som trängningsinkontinens. Vi fann att sängvätning i barndomen var en riskfaktor för nästan alla typer av bäckenbottenbesvär i vuxen ålder.

I den avslutande studien kartlades förekomsten av ofrivilligt tarmläckage. Vi fann att den dominerande typen av tarmläckage var för lös avföring, och förekom hos $>90 \%$ av alla kvinnor i undersökningen som rapporterade tarmläckage. Läckage av enbart fast avföring var sällsynt. Förekomsten av avföringsläckage ökade signifikant med åldern och BMI och läckagemönstret visade stora likheter med det som rapporterats hos kvinnor med irritabel tarm syndromet (IBS).

\section{Konklusion}

Under 40-årsperioden från 25 till 64 års ålder ökade förekomsten av alla undersökta bäckenbottenbesvär, särskilt urininkontinens. Ålder, BMI och sängvätning i barndomen var viktiga riskfaktorer för senare symtom på urin- och avföringsläckage och prolaps. Symtom på framfall i enkätstudier överskattar sannolikt i betydande grad den verkliga förekomsten av framfall hos fr.a. yngre kvinnor. Denna slutsats stödjas av det är mycket sällsynt att en kvinna 
som inte har fött barn behöver genomgå prolapskirurgi. Tarmläckage förekommer även hos kvinnor som inte fött barn och är sannolikt nästan uteslutande förknippat med s.k. IBS (Irritable Bowel Syndrome). Sammantaget visar våra studier att bäckenbotten, också hos kvinnor som inte fött barn har svagheter som medför ökad risk för bäckenbottenstörningar. 


\section{List of papers}

This thesis is based on the following papers, which will be referred to in the text by their roman numerals.

I. Urinary incontinence in nulliparous women aged 25-64 years: a national survey. AlMukhtar Othman J, Åkervall S, Milsom I, Gyhagen M. Am J Obstet Gynecol 2017 Feb;216(2):149. e1-149.e11. doi: 10.1016/j.ajog.2016.09.104.

II. The symptom of vaginal bulging in nulliparous women aged 25-64 years: a national cohort study. Gyhagen M, Al-Mukhtar Othman J, Åkervall S, Nilsson I, Milsom I. Int Urogynecol J 2019 Apr;30(4):639-647. doi: 10.1007/s00192-018-3684-5.

III. Childhood nocturnal enuresis-a marker for pelvic floor disorders and urinary tract symptoms in women? Al-Mukhtar Othman J, Åkervall S, Molin M, Gyhagen M. Int Urogynecol J 2021 Feb;32(2):359-365. doi: 10.1007/s00192-020-04345-x.

IV. Fecal incontinence in non-pregnant nulliparous women aged 25-64 years- a randomly selected national cohort prevalence study. Al-Mukhtar Othman J, Åkervall S, Nilsson IAK, Molin M, Milsom I, Gyhagen M. Am J Obstet Gynecol. 2021 Nov 11: S00029378(21)01229-1. doi: 10.1016/j.ajog.2021.11.032. Online ahead of print. PMID: 34774822 


\section{Content}

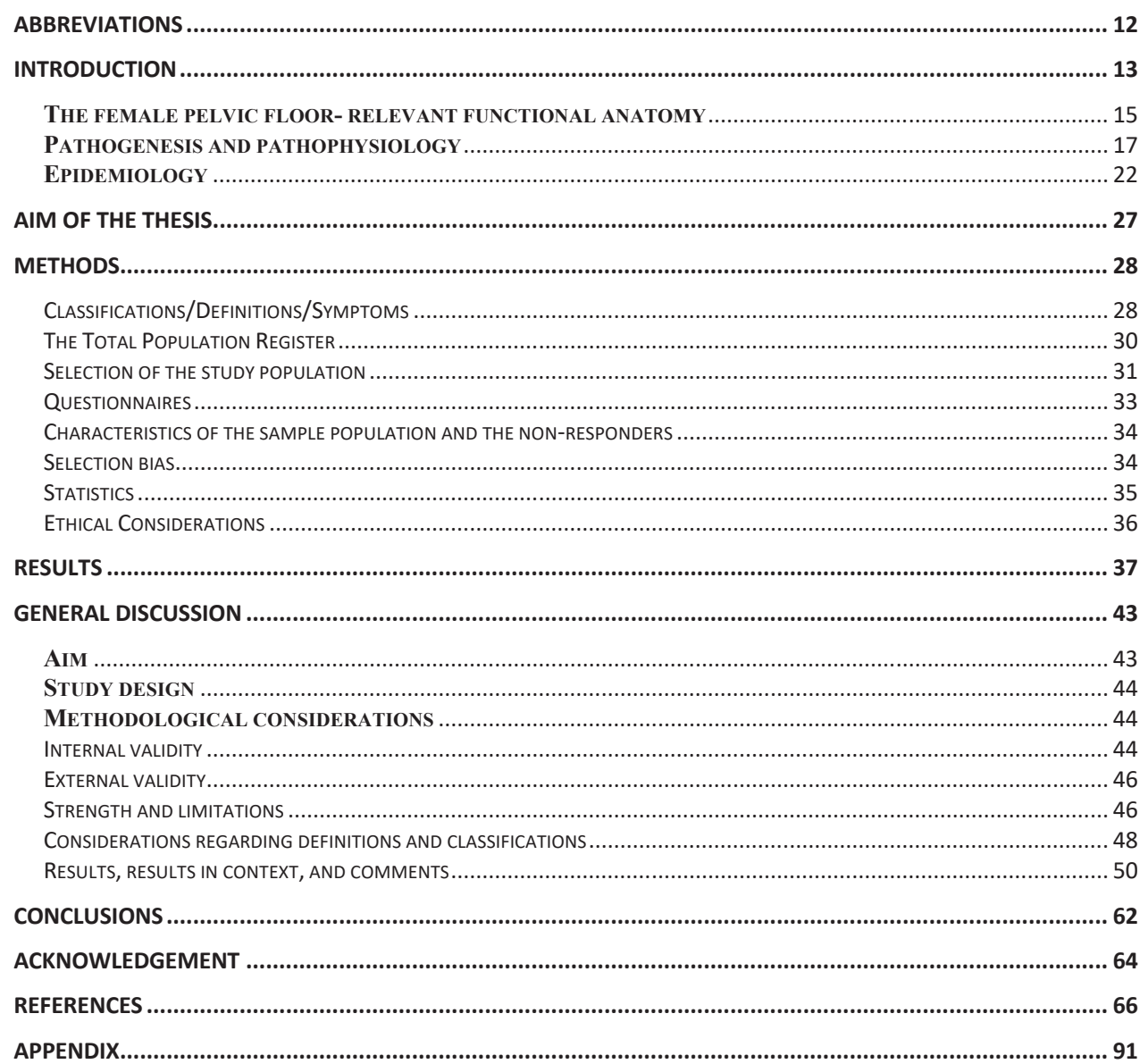




\section{Abbreviations}

BMI Body mass index

CNE Childhood nocturnal enuresis

DSM-5 Diagnostic and Statistical Manual of Mental disorders

FI Fecal incontinence

ICS International Continence Society

IGI Isolated gas incontinence

IUGA International Urogynecological Association

LUTS Lower urinary tract symptoms

MUI Mixed urinary incontinence

OAB Overactive bladder

OASI Obstetric anal sphincter injury

PFD Pelvic floor disorder

PIN Personal identification number

PNTML Pudendal nerve terminal latency

POP Pelvic organ prolapse

POP-Q Pelvic Organ Prolapse Quantification

sPOP Symptomatic pelvic organ prolapse

SUI Stress urinary incontinence

TPR Total population register

UI Urinary incontinence

UUI Urge/Urgency urinary incontinence 


\section{Introduction}

Pelvic floor disorders (PFDs) are a public health problem, the impact of which extends beyond physical manifestations. PFD is an umbrella term for several clinical conditions: the most common PFDs are Urinary Incontinence (UI), Pelvic Organ Prolapse (POP), and Fecal Incontinence (FI), but also including sensory symptoms involving bladder and bowel storage and voiding dysfunction, sexual dysfunction and chronic pelvic pain. These conditions have a negative impact on self-esteem, sexuality, body image, and the quality of life in women of all ages (1).

Millions of women worldwide are affected by PFDs. The lifetime risk for PFDs in women in welfare states is about $25 \%$ (2), and to undergo surgery for UI and POP is $20 \%$ before the age of $80-85$ years (3-5). PFDs often coexist. 15\% of middle-aged one-para women in Sweden had two or more PFDs and $46 \%$ at least one (6). $62 \%$ of women with symptoms of POP had concomitant UI after one vaginal birth (7).

Given the increase of the ageing population worldwide and the growing awareness of PFDs, the number of women seeking treatment for these conditions is expected to increase. It has been predicted that 58.2 million women in the United States alone will have at least one pelvic floor disorder by 2050, but even this number may be underestimated due to underreporting $(8,9)$. Globally, PFDs represent a considerable burden to healthcare systems and society (10). In Sweden, the costs of medical interventions, surgical treatments, and incontinence aids for UI have accounted for approximately $2 \%$ of the total healthcare budget (11).

Treatment of PFDs is challenging with uncertain long-term outcomes. After mid-urethral sling surgery for stress urinary incontinence (SUI), 9-12\% of women require further 
incontinence surgery $(12,13)$.

Genital prolapse surgery is associated with a high rate of failure and reoperation in up to $30 \%$ of cases (14-17), although rates in Sweden are slightly lower up to $13 \%$ (18). Surgical and nonsurgical management of faecal incontinence is often complex and unsatisfactory (19). Since treatment is not optimal, prevention strategies targeting modifiable risk factors should be a primary goal. Therefore, a better understanding of the aetiology and natural history of PFDs is essential.

Parity, mode of delivery, and adverse obstetric events such as sphincter rupture are wellestablished risk factors for PFDs. Nevertheless, knowledge about the influence of pregnancy itself on the development of PFDs later in life is limited. Some studies have claimed that pregnancy rather than vaginal delivery is responsible for most PFDs $(20,21)$.

Therefore, examining the prevalence of PFDs in a group of women not exposed to pregnancy and childbirth will provide insight into the natural history of the condition and will allow factors associated with PFDs such as age and body mass index (BMI) to be examined without the confounding effect of obstetrical adverse events. This group of women is poorly studied, and the literature provides limited and fragmentary information on nulliparous women. The SWEPOP-0 project (Swedish Pregnancy Obesity and Pelvic floor in nulliparous women) aimed to address this controversial topic. To estimate the relative impact of pregnancy per se, non-pregnant nulliparous women were compared with 1-para women with one caesarean section.

In this work, the prevalence of UI, sPOP, and FI and the impact of childhood nocturnal enuresis (CNE) were examined in a large cohort of non-pregnant nulliparous women aged 2564 years. 


\section{The female pelvic floor- relevant functional anatomy}

The female pelvic floor has a crucial role in maintaining urinary and fecal continence and childbirth $(22,23)$. The pelvic floor consists of several components, the peritoneum, pelvic organs, endopelvic fascia, the levator ani muscles, the perineal body and membranes, and superficial genital muscles (24).

The endopelvic fascia is an enveloping connective tissue network that connects the pelvic organs to the pelvic wall. Part of the fascia, the parametrium, attaches to the uterus and the paracolpium to the vagina. The endopelvic fascia provides support at three levels, described by DeLancey in $1992(25)$.

Level I: The cardinal-uterosacral ligament complex stabilizes the upper third of the vagina. Level II: The arcus tendinous fascia pelvis, the middle third of the vagina.

Level III: The perineal membrane and perineal body the lower third of the vagina. The levator ani muscle is functionally the main component of the pelvic floor and, together with the coccygeus muscle, forms the pelvic diaphragm. It is in a constant state of contraction and thus provides an active pelvic floor to balance intra-abdominal pressure and mechanical pressures during body movement and maintains continence (26). The levator ani temporarily relaxes during voiding (bladder emptying and defecation) and during childbirth. The urethra, vagina, and rectum pass through openings in the levator ani muscles to form what is known as the urogenital hiatus and the rectal hiatus. The interaction between the endopelvic fascia and the levator ani is critical in supporting the pelvic floor. The perineal membrane, formerly called the urogenital diaphragm, is a connective tissue system located at the level of the hymen that surrounds the urethra. It connects the urethra, vagina, and perineal body to the ischiopubic rami. It has the critical function of pressing on the distal urethra during a sudden increase in intra-abdominal pressure (24). 


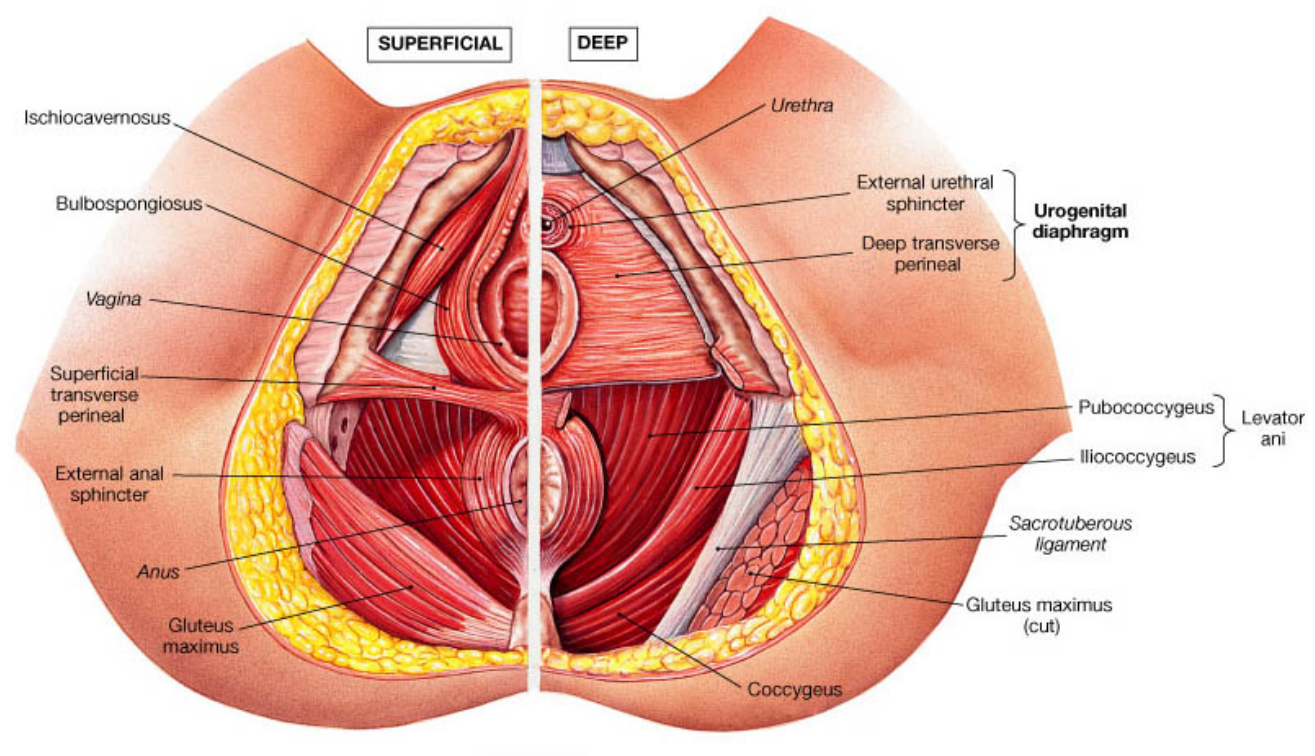

(a) Female

Female pelvic floor anatomy, superficial and deep view (www.anatomynote.com)

The anal sphincter complex consists of the internal anal sphincter (IAS), the external anal sphincter (EAS), and the levator plate. The levator plate is the point where the pubococcygeus, iliococcygeus, and puborectalis, parts of the levator ani muscle, converge to form the anorectal muscle sling (27).

The IAS, a thickened extension of the smooth muscle layer of the colon, is responsible for up to $60 \%$ of the resting tone and ensures that the anal canal is closed (28). Other components contributing to anal closing pressure include the EAS, anal mucosal folds, and the puborectalis muscle (29). The muscles of the anal sphincter complex overlap. The superficial part of the EAS merges with the perineal body, with contributions from the right and left 
superficial transverse perineal muscles. The deep part of the EAS is integrated into the puborectalis (30).

The sacral plexus is a nerve plexus formed by the lumbosacral trunk (L4, L5) and the sacral spinal nerves (S1 - S4). Through its various divisions, it is responsible for the innervation of the pelvic floor. The pudendal nerve belongs to the anterior division, originates from S2-S4, and supplies the urethral and anal sphincters and the perineal muscles. The anterior levator nerve arises from S3-S5 and supplies the main muscles of the pelvic floor (31).

\section{Pathogenesis and pathophysiology}

\section{Urinary incontinence}

Urinary continence is maintained by the compliance of the bladder and successful closure of the urethral sphincter and distal end of the urethra. According to the Integral Theory, which is now widely accepted to explain the pathogenesis of UI, there are three closure mechanisms for the urethra. The first closure mechanism is achieved by contraction of the anterior portion of the pubococcygeus muscle, which seals the distal end of the urethra and pushes the vagina anteriorly against the pubo-urethral ligament. The second closure mechanism is achieved by the downward and backward movement of the bladder neck against an immobilized proximal urethra, bending the bladder neck like a tube. The first two mechanisms are involuntary, and the third mechanism is achieved by the voluntary contraction of a group of pelvic floor muscles (32). The three mechanisms are dependent on the stability of the endopelvic fascia and the function of the levator ani muscle acting as an integrated unit to ensure urethral support (33). 
There are several factors that challenge the continence mechanism and lead to UI.

Damage to any element of the continence control system can impair a women's ability to remain continent in the face of increased intra-abdominal pressure resulting in stress urinary incontinence (SUI). Overactivity of the detrusor is thought to be the cause of urge urinary incontinence (UUI) and overactive bladder (OAB). The smooth muscle of the unstable bladder often shows increased spontaneous contractile activity, leading to a prematurely activated micturition reflex. This trigger is thought to be due to the inability of the vagina to tense sufficiently to modulate sensory input. This could be due to the laxity of the pubourethral and utero-sacral ligaments and the loss of contractile efficacy of the pubococcygeus muscle and levator plate (34). The pathogenesis of the UUI is multifactorial and complex. Disturbances in nerves, smooth muscle and urothelium can cause OAB and UUI (35). Age is an important risk factor for UI, and the mechanism is thought to be due to hormonal, neurogenic, and muscular changes with age $(36,37)$. Maximal urethral closure pressure decreases linearly with age (38). Ageing is associated with an increase in intramuscular collagen throughout the pelvic floor muscles, regardless of parity, resulting in fibrosis in all pelvic floor muscles, reducing muscle performance (39). These structural changes destabilize urethral support and reduce the pressure gradient that must be overcome when there is a sudden increase in intra-abdominal pressure, and are therefore associated with SUI (33). Age-related ultrastructural changes in smooth muscle, molecular changes in urothelial afferent signalling, changes in central nervous system pathways, and concomitant diseases (dementia, stroke, diabetes) account for the increased prevalence of detrusor overactivity and UUI in the elderly (40). 
BMI is generally accepted as a risk factor for urinary incontinence $(41,42)$. High BMI is thought to cause a chronic state of increased intra-abdominal pressure that stresses the pelvic floor (43). Santaniello et al., found an association between overweight/obesity and stress, urge and mixed urinary incontinence (44). In another study the authors concluded that high waist circumference rather than high BMI may be a sensitive marker for stress incontinence in women (45).

There is currently no evidence that detrusor function is impaired in obese women and there is no correlation with urodynamic parameters in obese women (46).

\section{Pelvic organ prolapse}

Vaginal delivery is the main risk factor for the development of POP later in life $(47,48)$. Stretch and compression to the levator ani muscle, pudendal nerve, and endopelvic fascia occurs during the second stage of labour when the fetal head is crowning leading to ischemia and tissue damage $(49,50)$.

Familial predisposition is a recognized risk factor for POP $(51,52)$. Five single nucleotide polymorphisms are significantly associated with POP (53); such a polymorphism may increase susceptibility to early-onset POP $(54,55)$. The prevalence of POP is known to increase with age $(56,57)$. Age-related changes in the intrinsic structure of the pelvic floor muscles occur independently of childbirth (39).

Other important risk factors include overweight and obesity and straining at stool, which all share the same mechanism of high abdominal pressure leading to global pelvic floor dysfunction (58-60). Many cross-sectional studies indicate that hysterectomy is a risk factor 
for POP, in particular apical POP as it contributes to the weakening of the supporting tissues of the pelvic floor $(61,62)$.

\section{Faecal and anal incontinence}

Bowel continence is maintained by the coordination of a functioning anal sphincter complex, intact anorectal sensation, rectal compliance, and the ability to consciously control defecation. Incontinence often develops from a combination of sphincter dysfunction and sensory impairment in the anorectum. Both liquid stool and a non-compliant rectum due to radiation or inflammatory colitis, may overwhelm the continence mechanisms even in individuals without a history of sphincter trauma (63-66).

There are numerous risk factors for FI. In parous women, obstetric anal sphincter injury is an important etiologic factor for FI later in life (67). Pudendal nerve conduction time abnormalities have been implicated in the pathogenesis of FI even in the absence of anatomic sphincter injury (68). Injuries to the pudendal nerve may occur during childbirth, probably due to stretching of the nerves or direct trauma during the passage of the fetal head through the birth canal $(68,69)$. Excessive straining due to long-standing constipation may result in injury to the pudendal nerve and progressive denervation of the pelvic floor muscles (70). Pudendal nerve terminal motor latency (PNTML) has also been shown to be influenced by age and is usually prolonged in older women $(71,72)$.

Endoanal ultrasound studies have demonstrated age-related atrophy in nulliparous women which has been confirmed by MRI studies (73). Rectal sensitivity decreases with age, but reports about age-related changes in anal squeeze pressures (external sphincter function) are contradictory (74-76). 
The impact of overweight $(\mathrm{BMI} \geq 25)$ and obesity $(\mathrm{BMI} \geq 30)$ on $\mathrm{FI}$ and $\mathrm{AI}$ is confounded by several other factors associated with incontinence, such as smoking, eating habits, and diabetes $(77,78)$.

Obesity may be associated with FI through many pathways. Obesity is associated with diarrhoea, via diabetes mellitus type II and its medications, excessive intake of low-fibre diet, and bile acid diarrhoea after cholecystectomy (78). Diarrhea occurs in 5-35\% of those with diabetes mellitus type II (79) and diarrhea was the strongest risk factor for FI, identified in several population-based studies (80). Obesity is also associated with a chronic increase in intra-abdominal pressure and thus contributes to the pathophysiology of FI (81).

\section{Childhood nocturnal enuresis}

CNE is defined as bedwetting in children $\geq 5$ years of age and is further classified as monosymptomatic, if CNE is not associated with other lower urinary tract symptoms (LUTS) or as non-monosymptomatic CNE, if associated with a LUTS symptom. Many epidemiological reports have shown a strong and consistent familial aggregation of CNE (82). Clinically, it is a heterogeneous condition with a complex mode of inheritance (83). Twin studies have indicated that CNE may have a genetic background, and the mode of inheritance is thought to be autosomal dominant. However, sporadic and environmental factors are thought to exert a strong modulating effect in one-third of cases (1). The primary pathogenesis is impaired arousal to the sensation of a full bladder during sleep in primary CNE (84-86), while detrusor instability plays a significant role in secondary CNE (86). Bowel dysfunction in children may be associated with CNE, epidemiological studies have shown that encopresis is a risk factor for $\operatorname{CNE}(87,88)$. The association between constipation 
and CNE is controversial, some studies showed no association and others showed that constipation may cause secondary enuresis or make primary CNE persist (89).

\section{Epidemiology}

\section{Urinary incontinence}

Prevalence rates of UI reported by large population studies vary widely, ranging from 5-69\%. This diversity is due to different definitions of UI, heterogeneity of the populations studied, and differences in the methodology of the studies. However, most studies report a prevalence of "any UI " in the range of $25-45 \%$, and $10 \%$ of women report at least weekly urinary leakage $(82,90)$.

Despite the diversity of UI prevalence, the distribution of UI subtypes appears to be consistent. Most studies report a prevalence of $10-39 \%$ for stress urinary incontinence (SUI), 7.5-25\% for mixed urinary incontinence (MUI), and 1-7\% for urge urinary incontinence (UUI) (82).

The prevalence of UI increases steadily with increasing age. SUI tends to dominate in younger women, and its prevalence decreases with age, whereas the prevalence of UUI and MUI tends to increase with age. Isolated SUI has a maximum around 30-49 years (91). Menopause per se has no effect on the prevalence of UI (82). The prevalence of UI is $10-25 \%$ in nulliparous women (92-94), and increases with increasing parity $(20,42,95)$. Systematic reviews including cross-sectional, longitudinal, and intervention data have found a positive correlation between $\mathrm{BMI}$ and $\mathrm{UI}$ and obese women $(\mathrm{BMI} \geq 30)$ has been shown to have twice the risk of UI $(96,97)$. The association between BMI and UI, severe UI and subtypes of UI (SUI, MUI) is consistent across all age groups and rather constant in relation to other risk factors $(96,98)$. 
Several studies have shown that early onset of obesity is associated with an increased risk of UI in middle age $(99,100)$. Both high BMI and weight gain are associated with an increased risk of UI, women who had gained 5-10 kg were more likely to have weekly incontinence than women who maintained their weight within $2 \mathrm{~kg}$, and the odds nearly tripled among women who gained more than $30 \mathrm{~kg}$ since early adulthood; the association is more significant for SUI and MUI than for UUI $(99,101,102)$. Central obesity, waist circumference, and waist-to-hip ratio appear to be associated with SUI $(101,103)$ and UUI $(104,105)$. Intervention studies of weight loss have shown that even modest weight loss is associated with improvement or resolution of SUI and UUI, with the likelihood of resolution correlating to the degree of weight loss (106-109).

Vaginal delivery is thought to increase UI prevalence with the risk being greatest after the first delivery and increasing after each subsequent delivery $(20,42,95,101)$. Meanwhile, many studies have shown the protective effect of caesarean section for UI (20, 110-112). Pre-pregnancy UI and UI during pregnancy are independent risk factors for postpartum UI $(113,114)$. SUI and MUI worsen during pregnancy and childbirth, whereas the prevalence of UUI was unaffected $(115,116)$.

Hysterectomy, in particular vaginal hysterectomy appears to increase the risk of UI and subsequent surgery for SUI (61).

There is strong evidence that oral oestrogens, with or without progesterone, increase the incidence of UI and the severity of UI (117), while studies support the use of local oestrogens to treat UI in postmenopausal women (118). 


\section{Pelvic organ prolapse}

The prevalence of POP varies widely and is difficult to determine because of the disparity of POP diagnostic methods used by different studies. Studies that relied on questionnaires (symptoms of POP) reported a prevalence of 3-7\%, while those that used clinical examinations reported a higher prevalence of up to $56 \%(119,120)$.

POP is a rare condition in nulliparous women, occurring in $0.3-2.4 \%(2,121,122)$. Although pregnancy itself has been identified as a risk factor for POP (123), vaginal delivery is the most significant risk factor for developing POP $(7,48,57,124-126)$. POP risk increases with increasing parity and number of vaginal deliveries $(2,124,126)$. Caesarean section has been shown to reduce the risk of POP later in life $(7,47,126-128)$.

Studies have shown that the prevalence of prolapse increases with age $(2,122,129)$. Olsen et al. showed that the lifetime risk of undergoing a single operation for prolapse or incontinence by age 80 was $11.1 \%(3-5)$.

The impact of BMI on the prevalence of POP is controversial. Some studies have shown that the prevalence of POP increases with increasing BMI $(57,130)$. Gyhagen et al. demonstrated that sPOP increased by $3 \%$ with each unit increase in current BMI (7). Kudish et al. found that the risk of prolapse progression increased by $12-26 \%$ in overweight and obese women compared with women with a $\mathrm{BMI}<25$ and that weight loss was not associated with prolapse regression, suggesting that pelvic floor damage associated with weight gain may be irreversible (131).

Other studies showed that BMI had no effect on the prevalence of POP $(124,129)$.

Constipation and repetitive straining at stool are associated with a higher prevalence of sPOP (60). 


\section{Fecal and anal incontinence}

There is considerable variation in the reported prevalence, reflecting heterogeneity in study designs, different cut-offs in frequency and the type of stool leakage included when defining bowel incontinence. The prevalence of AI, which also includes isolated gas leakage, has been reported to be significantly higher $(2.2-47 \%)(80,132)$.

The impact of pregnancy on bowel incontinence is thought to be low, $10 \%$ of nulliparous pregnant women reported AI, of whom 90\% had gas incontinence only (133), However, postpartum FI /AI is common in the first 3-6 months after delivery $(134,135)$, with the majority of women having a good chance of recovery (136). A meta-analysis by Oberwalder et al. has shown that in women with post-partum FI, the probability of an anal sphincter defect diagnosed by endoanal ultrasound was $77-83 \%(137)$.

The prevalence of FI increases steadily with age in both men and women (80). The association with age in parous women is probably non-linear due to the late onset of FI years after birth (138).

Data on the association of BMI and FI are conflicting; some reports state that BMI is a risk factor for FI $(81,139-141)$, while others report no association $(80,142)$.

Diarrhea or liquid stool, due to various etiologies, is a significant risk factor for FI and AI (138). One study showed that every second individual with diarrhea has FI (143). 


\section{Childhood nocturnal enuresis}

CNE is defined as bedwetting at the age of five or more. The condition is more common in boys, but sex differences decrease with age $(144,145)$. The prevalence of CNE in children aged 7 years varies in different studies. Most studies estimate the prevalence to be $7-10 \%$. The condition improves with age. By age 11-12 years, the prevalence decreases to $1.7-4.8 \%$, with a remission rate of $15 \%$ per year (1). A further decrease in the prevalence of CNE is seen at age $16-17$ years and is reported to be $0.5-1.7 \%$, with a remission rate of $11 \%$ per year. The overall prevalence of nocturnal enuresis in adults is approximately $0.5 \%$, suggesting that some children remain enuretic into adulthood (146). An association between CNE and selected lower urinary tract symptoms in adulthood has been noted (147-151) 


\section{Aim of the thesis}

The overall aim was to describe in detail the age-related prevalence of PFDs and identify predictors of PFDs in a large, national, randomly selected cohort of nulliparous women aged 25 to 64 years. This knowledge is a necessary prerequisite for comparisons with parous women to elucidate the separate effect of pregnancy and the additive effect of vaginal delivery.

\section{The specific aims were:}

\section{Paper I}

The primary aim was to describe the age-related prevalence of UI, its severity, subtypes, emotional impact, and health care consequences. A secondary aim was to create an appropriate control group for comparisons with parous women to be able to establish the additional costs of women's reproductive burden, both in terms of pelvic floor health and economically.

\section{Paper II}

The primary aim of this study was to assess the prevalence of symptomatic pelvic organ prolapse (sPOP) in a national cohort of nulliparous women aged 25-64 years of age. A secondary analysis was performed to study the association between "vaginal bulging" and other pelvic floor symptoms and disorders to identify possible sources of spectrum bias.

\section{Paper III}

The aim of the study was to investigate the association between a history of CNE at $\geq 5$ years of age and a wide spectrum of PFDs in a large, nationwide, randomly selected cohort of adult nulliparous women aged 25 to 64 years. 


\section{Paper IV}

The aim of this study was to present detailed, descriptive measures of accidental leakage of liquid or solid stool and gas in a randomly selected, large national cohort of non-pregnant nulliparous women aged 25 to 64 years.

\section{Methods}

\section{Classifications/Definitions/Symptoms}

Women were classified as nulliparous if they were confirmed as not having given birth in the questionnaire, and at the same time, were identified as nulliparous by Statistics Sweden from the Total Population Register.

Age at 22/8/2014 and body mass index (BMI, $\left.\mathrm{kg} / \mathrm{m}^{2}\right)$ were calculated from self-reported height and weight in the questionnaire and classified as normal $(<25.0)$, overweight $(25.0$ 29.9), moderately obese (30.0-34.9), and severely obese ( $\geq 35.0)$.

UI, subtypes of UI, nocturia and overactive bladder (OAB) were defined according to the International Urogynecological Association (IUGA) / International Continence Society (ICS) definition (152). Any UI was defined by the question "Do you have involuntary loss of urine?". Duration of UI was categorized into UI lasting less than 5 years, 5 to 10 years or UI more than 10 years.

Women were classified as having SUI if they reported involuntary urine loss associated with coughing, sneezing, laughing, or lifting heavy objects. If incontinence occurred in conjunction with a sudden and strong urge to urinate, the participant was classified as having UUI. If both components were present, the participant was classified as MUI (152). 
Other UI was an affirmative of any UI, but no subtypes were specified. Nocturia was defined as an interruption of sleep $\geq 1 /$ night due to urination. A more restricted definition of nocturia, $\geq 2 /$ night, was used in paper IV.

Overactive bladder $(\mathrm{OAB})$ was defined as urinary urgency with or without incontinence, usually accompanied by frequency and nocturia. Frequency of incontinence was categorized as less than once per month/ once or more per month/ once or more per week/ and every day and/or night. The amount of leakage was categorized as "A few drops" versus "Small amount" and "Large amount".

The mental impact of UI, reported by incontinent women, was categorized as "A minor problem" (no problem/a small nuisance= not bothersome) and "Bothersome" (some bother/much bother/a major problem).

Symptoms of POP was defined by the question "Do you have a sensation of tissue protrusion (a vaginal bulge) from your vagina?" with the alternative answers Never= No, Infrequently/ Sometimes/ Often= Yes. Bothersome symptoms of POP were indicated by answering the question "How do these vaginal symptoms affect you?" and were dichotomized into two levels, "Not bothersome" = No problem/ A small nuisance and "Bothersome" = Some bother/ Much bother/ A major problem.

Childhood nocturnal enuresis (CNE) was defined according to the International Children Continence Society (ICCS) as a symptom and condition of intermittent incontinence during sleep at age $\geq 5$ years (153). Women were asked to answer the question: "Were you a bed wetter during childhood (involuntary loss of urine while sleeping)?" (yes/no). If so, at what age did it stop? 
FI was defined according to the IUGA/ICS as accidental leakage of solid and liquid stool with and without gas leakage. Anal incontinence (AI) as isolated gas incontinence (IGI) or FI with or without concomitant gas leakage (152). Gas leakage, when it occurs in combination with stool, was referred to as "any gas" as opposed to IGI, which refers to gas leakage as an isolated symptom of incontinence. The frequency of leakage was categorized as "Never", "Less than once a month", "Several times a month", "Once a week or more" and "Once a day or more". The mental impact of incontinence was dichotomized into "Not bothersome" = no problem/A small nuisance and "Bothersome" = Some bother/Much bother/A major problem. Severe bowel incontinence was defined as a condition that is bothersome and occurs several times a month or more often.

The questionnaire also included questions about the need of wearing a pad, and lifestyle changes.

\section{The Total Population Register}

The Total Population Register (TPR) was started by Statistics Sweden in 1968 and provides essential information on demographics. It forms the basis for official population statistics and is a source of data for other registers and surveys. It is a fundamental part of epidemiological research in Sweden.

Changes in the population register are reported five times a week by the Swedish Tax Agency, which has overall responsibility for the population register. Implicitly, $100 \%$ of births and deaths, $95 \%$ of immigrations and $91 \%$ of emigrations are reported to the population register within 4 weeks and with a higher proportion over time. 
The TPR is linked to the personal identity number (PIN), which consists of date of birth, birth number, and a check digit, allowing data linkage to other registers.

The strength of the TPR is its completeness and linkage to the PIN; however, it has some minor limitations. The most significant limitation is oversubscription, estimated at $0.5 \%$, due to underreporting of emigration. Undersubscription is usually temporary.

\section{Selection of the study population}

The study cohort was restricted to non-pregnant women with no births aged $25-64$ years. The Survey Division of Statistics Sweden identified these women from the TPR which includes $99 \%$ of all women in Sweden.

Statistics Sweden created a sampling frame of 627,049 eligible women (Figure 1). After PIN control, 1239 women were excluded due to misclassification by parity, death, emigration, and change in social security number. Four independent random samples were drawn from the 625,810 eligible women, stratified by age decade from 25-64 years. 19,981 women were invited to participate; they received an introductory letter with login credentials to a Webbased questionnaire, followed by a postal questionnaire. After three mailing cycles over 4 months, 10,187 women (52.2\%) responded. 264 women declined to participate or returned a questionnaire that could not be evaluated. In addition, 726 women were excluded, either because of ongoing pregnancy (194), as determined by questionnaire responses, or because of parity (525), or because of internal loss due to failure to answer important questions in the questionnaire. Thus, the final study population was 9,197 women. 


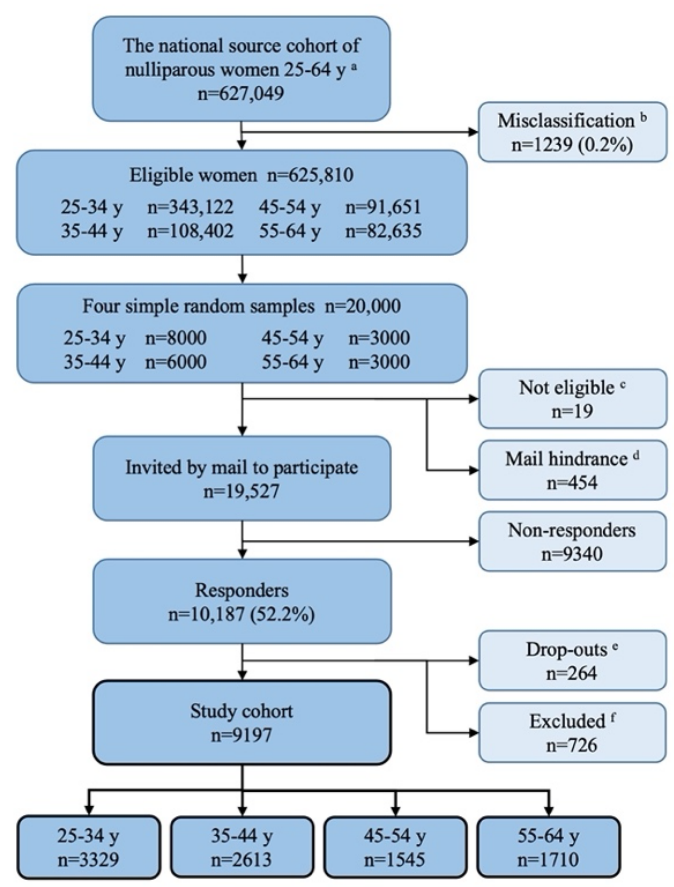

Figure 1. Flow chart of nulliparous women age 25-64 years identified from the Total Population Register

${ }^{\mathrm{a}}$ The source cohort denotes all nulliparous women, aged 25-64 years, registered in Sweden in 2014. ' $\mathrm{Misclassification} \mathrm{for} \mathrm{parity,} \mathrm{deceased,}$ emigrated, and change of social security number was discovered at an id-run performed by Statistics Sweden in January 2014 to exclude these categories. This information is updated every fourth week. 'Not eligible denotes women that had emigrated or died up to the start of the collection period. ${ }^{\mathrm{d}}$ Mail hindrance denotes mail returned to sender and address not found. ${ }^{e}$ Drop-outs denotes those who actively declined

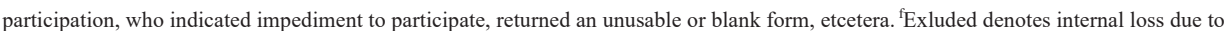
ongoing pregnancy, parity or key questions not being answered in the questionnaire 


\section{Questionnaires}

The 40-item questionnaire was distributed via the web and by mail. It included questions on demographics: current weight and height, menstruation, current pregnancy, deliveries, hysterectomy, menopause, and hormone treatment. These questions were followed by validated questions about pelvic floor disorders (PFDs), which served as both a symptom inventory and a measure of the extent of bother by PFDs.

The first section of the questionnaire addressed micturition habits. If the participant confirmed UI, further information was to be provided on the duration, frequency and quantity of urine leakage. The severity of urinary leakage was assessed using the Sandvik severity index (154).

The second section contained a validated question to predict the presence of symptoms of POP reported by Tegerstedt et al. (122), as well as questions about the frequency of symptoms and the degree.

In the third section, there were questions about bowel incontinence (solid, liquid stool or gas), its frequency, the need to wear pads, and the impact on daily life were asked. The severity of bowel incontinence was measured using the Wexner Continence Grading scale (155), a widely used scale as it is easy for patients to use.

Questions about help-seeking behaviour and treatment for PFD symptoms were included in the questionnaire (Appendix 1). 


\section{Characteristics of the sample population and the non-responders}

The response rate in this study was $52.2 \%$ after three mailing cycles over a four-month period. The response rate increased with age from $44.7 \%$ in the youngest group (25-34 years) to $62.4 \%$ in the oldest group (55-64 years). The overall response rate for the Web-based version of the questionnaire was $52 \%$, and was more common in the youngest age group, and decreased with age. In the youngest age group, $55 \%$ of respondents answered via the web. The corresponding figures for the remaining strata were 54\% for stratum II, 51\% for stratum III and $43 \%$ for stratum IV.

Non-responders were more often immigrants (63.7\%) compared to responders (36.3\%) and non-Swedish citizens (67.8\% vs. $32.2 \%$ of responders). Non-responders were also more likely to be unmarried (51.2\% vs. $48.8 \%$ ), to live in the suburbs of commuting municipalities (53.7\% vs. $46.3 \%)$, and to have lower income and lower education levels and a postsecondary education $\leq 3$ years in $40.9 \%$ vs. $59.1 \%$ (Appendix 2 ).

\section{Selection bias}

About every second woman answered the questionnaire after three mailing cycles over a fourmonth period. Some considerations of selection bias must therefore be made. It is known that women with symptoms are more likely to participate in studies; this could lead to an overestimation of prevalence of PFDs (156). In addition, when using questionnaires that include questions about past events, such as nocturnal enuresis in childhood, recall bias may occur, which could lead to overestimation of the association between CNE and PFDs. 
The symptoms in this study are self-reported; however, it has been shown in several studies that self-reported symptoms are consistent when present at the same time of reporting (157159).

Analyses of the non-responder group in this study, suggest selection bias. The non-responders were younger, and because PFDs are more common at older ages, PFD symptoms may be overrepresented among responders. The non-responder data suggest lower socioeconomic status (SES), which is known to be associated with many other predictors of PFDs (8).

\section{Statistics}

The statistical analyses of this thesis were performed with (SPSS Statistics 22, IBM Corp, Armonk, NY) in paper I and II and with SAS 9.4, SAS Inc., Cary, NC, USA in paper III and IV. Statistical models were built to calculate prevalence rates adjusted for relevant cohort characteristics, risk factors and confounders.

Descriptive data for continuous variables were presented as mean and standard deviation (SD), median, and interquartile range (IQR). Categorical variables were presented as numbers, percentage and 95\% confidence interval (CI). Results were presented as mean difference for continuous variables and the difference in percentages for categorical variables with $95 \% \mathrm{CI}$ and $\mathrm{P}$ value. Calculation of the $95 \% \mathrm{CI}$ for the difference between continuous variables was based on bootstrapping of 10,000 replicates, identifying the 2.5 and 97.5 percentiles of the mean difference. Age and BMI were treated as continuous variables or stratified as follows: Age categorized into 10-year groups 25-34, 35-44, 45-54, 55-64 years, BMI categorized into $<25.0,25.0-29.9,30-34.9, \geq 35$, or dichotomized into $\mathrm{BMI}<30$ or $\geq 30$ 
$\mathrm{kg} / \mathrm{m} 2$. Crude and adjusted prevalence and proportion and 95\% confidence intervals for all outcomes were calculated for each 10-year category.

The chi-square test and Fisher's exact test were used to compare two groups of categorical variables, and Student's t-test and Mann-Whitney U-test were used to compare between two groups with continuous variables. Pearson's correlation test was used to calculate the degree of correlation between UI and age in paper I. The trend between independent groups was analysed using the Mantel-Haenszel chi-square test for dichotomous outcomes and the Spearman rank correlation test for continuous variables. The Kruskal-Wallis test was used to analyse the trend between multiple ordered versus non-ordered categorical variables in paper IV. The estimated probability of outcome parameters was determined using logistic regression models and presented as a percentage and the 2-tailed 95\% CI of the probability estimate. Taking age and BMI into account, adjusted prevalence and odds ratio (OR) were calculated from the logistic regression model. Results were presented as age- and BMI-adjusted OR (AOR), 95\% CI and $\mathrm{P}$ value. No adjustment was made for multiple testing. A P value $<0.05$ was considered statistically significant. In each analysis, missing data were accounted for and excluded.

\section{Ethical Considerations}

Ethical approval was obtained from the Regional and the National Ethic Review Boards (Ethics Committee at Sahlgrenska Academy, Gothenburg University and National Board for Health and Welfare), reference no. 776-13; Nov. 18, 2013. All women received written information and gave written informed consent before participating in the study. 


\section{Results}

\section{Paper I}

The crude prevalence of UI increased linearly from $11.7 \%$ in the youngest age group to $24.9 \%$ in the oldest. The linear correlation between age and UI was highly significant $(\mathrm{r}=0.86)$. Prevalence increased 5-fold from $9.7 \%$ in the youngest women with normal BMI $(<25)$ to $48.4 \%$ in the oldest women with $\mathrm{BMI} \geq 35$. Similarly, leakage $\geq 1 /$ week increased almost 14-fold from 2.4 to $33.0 \%$, indicating that the combined effect of age and BMI was substantial. Bothersome UI almost tripled across all age groups from 2.8 to $7.9 \%$; its proportion increased from one in four to one in three (24.4-32.3\%) among incontinent women. Similarly, nocturia $\geq 2 /$ night increased fourfold to $17 \%$, and leakage $\geq 1 /$ week increased threefold to $12.8 \%$ in the oldest group. The leakage of more than a few drops increased threefold to $9.6 \%$. The number of daytime micturitions was similar across ages. The proportion of UI subtypes changed over time (Figure 2). MUI increased from 22.9 to $40.9 \%$ in the oldest women, while SUI decreased inversely from 43.6 to $33.0 \%$. The strongest association between BMI and age was found for MUI and bothersome UI. While UUI was associated with age but not BMI, SUI had a stronger association with BMI than with age. Only $0.3 \%$ of nulliparous women in the total cohort had undergone surgical treatment, $0.3 \%$ had received medical treatment, and $1.8 \%$ had seen a physician for UI. 


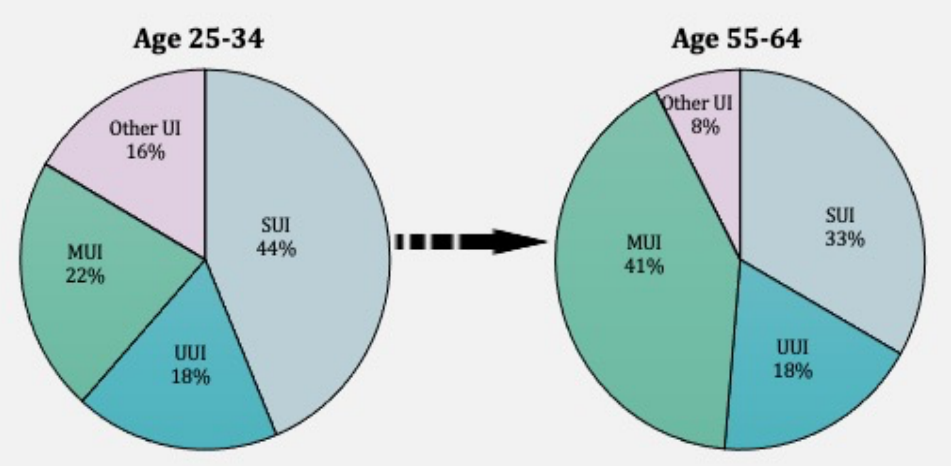

Figure 2. Change in the subtypes of UI over time

\section{Paper II}

The prevalence of feeling "a sensation of tissue protrusion (a vaginal bulge)", infrequently, or more often in nulliparous women was $7.9 \%$, sometimes or more often in $2.9 \%$, and often in $0.4 \%$. The BMI-adjusted prevalence of sPOP decreased in all age groups, from $9.8 \%$ in the youngest to $6.1 \%$ in the oldest group. Fifteen of the nulliparous women $(0.16 \%)$ had undergone surgery for prolapse. Bothersome sPOP was more common in the oldest age group, $21.7 \%$. 
Feeling of a vaginal bulge, reported as "often", was less common and increased with age from 3.9 to $7.0 \%$. Reporting an aggravation of the bulging sensation with heavy lifting was twice as common in the oldest women as in the youngest women $(22.5 \%$ vs $10.9 \%)$.

The symptom "vaginal/vulval rubbing/chafing feeling" was most common among the youngest $14.2 \%$ and decreased across ages to $7.8 \%$ among the oldest women. The association between "chafing" and sPOP was strong in all age groups (OR 4.29-6.87) and occurred three times more frequently in the youngest age group (e.g., 36.4 vs11.8\%).

The prevalence of urinary urgency/OAB was approximately twice as high in women with sPOP. FI occurred almost three times more frequently in women with sPOP $(22.9 \%$ in women aged 25-34 years) compared with women without sPOP (8.5\%) across all age groups. In contrast, the association between sPOP and UI and all subtypes of UI was inconsistent and weaker across all age groups. The presence of one or more concomitant genital symptoms, chafing, $\mathrm{OAB}$, or FI, was associated with increasing frequency of a bulging sensation. Clustering of pelvic floor symptoms was four times more common in women with sPOP $(23.2 \%$ vs $6.1 \%)$.

A logistic regression model showed that sPOP was associated with younger age $(<35$ years, OR $1.45 ; 95 \%$ CI $1.23-1.72$ ) but not with obesity (BMI $\geq 30$ ) or UI. Chafing was the strongest predictor of sPOP (OR 4.25; 95\% CI, 3.52-5.12), while OAB was a significant but weaker predictor for sPOP. 


\section{Paper III}

The 926 women with CNE (10.2\%) were younger (2.1 years), less likely to be postmenopausal $(10.9 \%$ vs. $17.9 \%, P<0.0001)$, and more likely to have a family history (mother) of UI compared with the 8140 women without CNE. CNE was more common in younger women aged 25 to 34 years $(11.4 \%)$ compared with older women aged 55 to 64 years (7.3\%), P for trend $<0.0001$. However, the association between CNE and adult PFDs was similar across ages.

The prevalence of UI was twice as high in women with CNE (14.8\% vs. 28.6\%, OR 2.50; 95\% CI, 2.12-2.94; $P<0.0001)$, and the prevalence of all subtypes of UI was also approximately twice as high in CNE-positive women. The strongest association was found for mixed UI (4.2\% vs 9.3\%, OR 2.63; 95\% CI, 2.03-3.40; $P<0.0001)$. In women without CNE, the prevalence of OAB was $18.4 \%$ compared to $32.6 \%$ in women with CNE (OR 2.34; $95 \%$ CI, 2.03-3.40; $P<0.0001$ ). Daytime micturition $\geq 8$ was $24.0 \%$ compared to $29.6 \%$ in the CNE group $(P<0.0001)$ and for nocturia $\geq 2 /$ night $7.8 \%$ compared to $12.4 \%(P<0.0001)$. Other PFDs not related to bladder symptoms, were also consistently higher in women with CNE. FI was $11.2 \%$ in the non-CNE group and $16.8 \%$ in the CNE group $(P<0.0001)$ and sPOP was $2.6 \%$ compared to $4.8 \%$ (OR 1.82; $95 \%$ CI, $1.31-2.55 ; P=0.0004$ ) (Figure 3 ). 


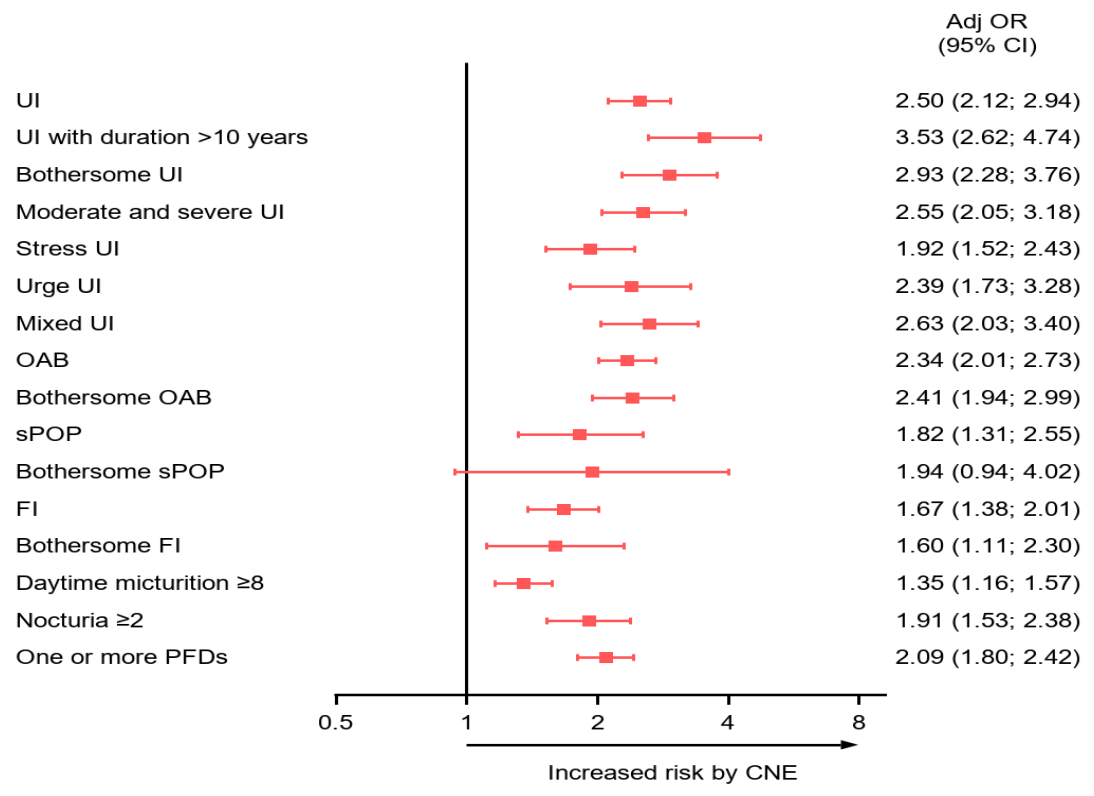

Figure 3. Risk for pelvic floor disorders in nulliparous women with a history of childhood nocturnal enuresis

Surgery for UI was rare in both groups $(<1 \%)$, but significantly more common in the CNEpositive group ( 0.3 versus $0.8 \%, P=0.02)$, while medication was similar for UI and OAB. The rate of missing data varied between $0.3 \%$ and $1.9 \%$ for different outcomes.

\section{Paper IV}

The prevalence of FI was 9.7\% (95\% CI, 8.7-10.7) among women aged 25-34 years and $15.7 \%(95 \%$ CI, 14.0-17.5) in women aged 55-64 years (Figure 4). The age-related BMIadjusted risk increase of FI was AOR $10 \mathrm{yr} 1.19(95 \% \mathrm{CI}, 1.13-1.25, P<.0001)$. The estimated probability of FI was $8.8 \%$ at age 25 and $17.6 \%$ at 64 years. The rate of severe FI was considerably lower, from $1.0 \%$ in women aged 25 to $2.3 \%$ at 64 years respectively, with an 
age-related risk increase of $\mathrm{AOR}_{10 \mathrm{yr}} 1.31$ (95\% CI, 1.12-1.52). The age-related association to AI, IGI, severe AI, and severe IGI was weak or absent. The incidence of FI and severe FI seemed to plateau in ages up to 45 and above 50 years of age, with an interval of increased incidence between age 40 and 50. Except for IGI, a similar pattern was observed for all measures of incontinence.

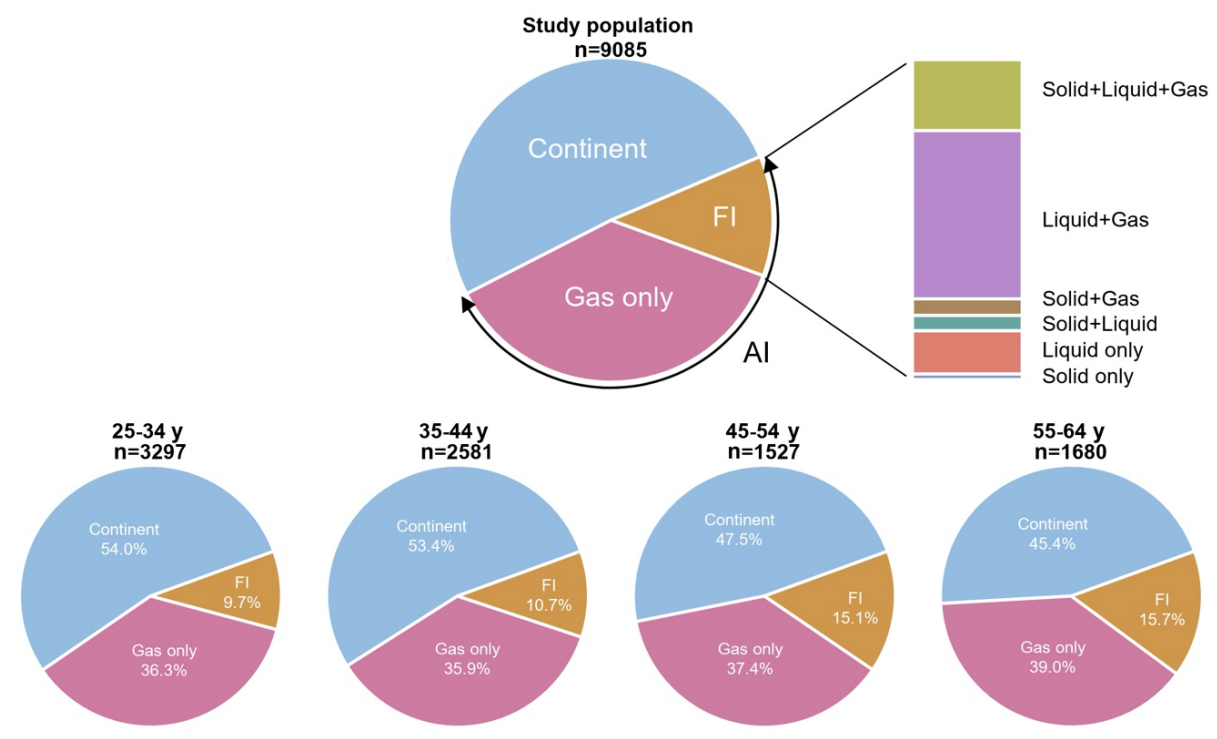

Figure 4. Age-related prevalence of different measures of incontinence

Leakage of liquid stool was the dominant type of leakage 93.1\% (95\% CI, 91.4-94.5), whereas leakage of solid stool occurred in $33.9 \%$ (95\% CI, 31.1-36.7). However, solid and liquid stool leakage were combined in $\sim 80 \%$. Conversely, only $29.0 \%$ (95\% CI, 26.2-31.8) of women with liquid stool leakage also had leakage of solid stool. The combination of stool with gas was observed in $\sim 80 \%$. The age-related BMI-adjusted risk increase per 10 years for leakage of any liquid stool was AOR 10yr 1.19 (95\% CI, 1.12-1.25) and for any solid stool 
AOR $_{10 y r} 1.11$ (95\% CI, 1.05-1.21). The estimated probability of solid stool leakage with or without concomitant gas (excluding liquid stool) was $0.8 \%$ at age 25 and $1.1 \%$ at 64 years. Similarly, liquid stool occurred in $8.3 \%$ at age 25 and $12.2 \%$ at 64 years. The two dominant combinations were liquid +gas (52.6\%) and the triple combination solid+liquid+gas $(22.2 \%)$. The pattern of distribution between the different single or combined types of leakage was similar in all age groups (Trend $P=0.33$ ). All measures of incontinence except IGI increased with BMI. BMI and age were risk factors for FI $(P<0.0001)$ with an interaction effect of $P=0.16$. The estimated probability of FI was $8.0 \%$ at 25 years and BMI 20 and at 64 years and BMI 40 , the probability was $29.6 \%$.

\title{
General discussion
}

\author{
Aim \\ To our knowledge, there has been no survey of different aspects of PFDs that has studied a \\ large sample of exclusively nulliparous women of different ages. The primary aim was to \\ describe the prevalence and age-related change of PFDs in nulliparous women. A cohort \\ restricted to nulliparous women is optimal for studying the background influence of age on \\ PFDs. Further, the nulliparous group constitutes a reference group to elucidate the effect of \\ pregnancy itself on the pelvic floor. Nulliparous women lack confounding factors associated \\ with pregnancy and possible obstetric adverse events, multiple births and mixed delivery \\ modes.
}




\section{Study design}

We, therefore, designed a study including 20000 nulliparous women. These women were retrieved by Statistics Sweden from the TPR. Inclusion criteria for the study were nonpregnant women aged 25-64 years who had not given birth and were 25-64 years of age. The lower limit of the age span was set to 25 years because studies of adolescent girls and young women indicate that the prevalence of PFDs, especially UI, have been shown to stabilize in the third decade.

The 20000 participants were grouped into four independent simple random samples, stratified by decades of age. The cohort was oversampled for the two youngest age groups intended for a subsequent longitudinal follow-up study. The eligible nullipara women were investigated using a web or postal 40-item questionnaire about PFDs conducted in 2014. The questionnaire was answered by 10187 women, after 3 mailing cycles during a 4-month period. The web form was used by $52 \%$.

\section{Methodological considerations}

\section{Internal validity}

Internal validity is achieved when the study design reflects what was observed, and the conclusion can be attributed to the influence of the independent factors rather than confounding factors. Bias and systematic error compromise internal validity (160). 


\section{Information bias}

In this study, data were collected from the Total Population Register (TPR) based on administrative data from the Swedish Tax Agency which has a high coverage of almost $100 \%$.

However, parity data are occasionally inaccurate due to migration. Therefore, a control question on pregnancy and parity was included in the questionnaire. Data on current weight, height, and PFD symptoms were reported by participants via the questionnaire and are dependent on participants' willingness and ability to provide accurate information. However, misinterpretation of questions, inaccurate current weight and height data and the social desirability of answering questions on sensitive topics may underestimate or overestimate the associations and prevalence rates (161).

\section{Selection bias}

Symptomatic women may be overrepresented because they may be more willing to participate in studies compared with asymptomatic women (156). Analysis of the non-responder group revealed that older women had a higher response rate than younger women, suggesting that women with symptoms, which are more prevalent in older groups, are more willing to respond. This could inflate prevalence rates.

This study, like other cohort studies, is based on the assumption that a group of young women today is an adequate substitute for older women from the past that they must follow paths of change calculated from arithmetic lines of best fit. Thus, the results may be biased by time- 
dependent intergenerational differences that result from changes in characteristics and experiences during different calendar periods rather than from pure age-related changes.

\section{External validity}

External validity refers to the ability to generalize the results of the study. The study population was a large random sample with reliable information about: nulliparity; exclusion of possible current pregnancy; provided age and BMI; covering 40 years, resulting in a high generalizability of our results. The results cannot be generalized to pregnant or parous women. The population studied in this thesis was predominantly Caucasian; therefore, results for other ethnic groups should be cautioned.

\section{Strengths and limitations}

One of the strengths of this study is the large, randomly selected cohort of women from a national register from a homogeneous Nordic population. The design and statistics of this study were aimed to improve the control of confounding factors in order to increase precision, accuracy and efficiency of valid results. Another strength was that the nulliparous cohort covered a period from 25 to 64 years of age. The nulliparous cohort was restricted to women younger than 65 years to avoid confounding by age-related diseases. The questionnaire contained validated questions about UI, sPOP and AI/FI according to the IUGA/ICS definitions. Nulliparity was verified in the TPR and controlled for in the questionnaire. One of the limitations was that symptoms and their severity were self-reported and therefore dependent on participants' willingness and ability to report them, which may change with age. However, self-reported symptoms were considered the most appropriate tool for eliciting 
information about sensitive topics (156) and are consistent and valid when present at the time of reporting $(158,159)$. Surveys that include past events (such as CNE) carry a risk of recall bias; however, the response rate for this question was exceptionally high (99\%). CNE was more often reported in younger women compared with older, likely due to forgetfulness coming with age, but may also be due to a generational shift in attitudes toward the stigma of CNE.

The participation rate was $52 \%$, which is consistent with other epidemiological studies in the field (162). The response rate increased steadily with age, from $43 \%$ in the youngest group to $63 \%$ in the oldest age group. This suggests that the older women may be more compliant and motivated to respond, but it could also be because they are more likely to have symptoms and be willing to respond. Since symptoms are more common in older women, this may have overestimated the overall prevalence. Generally, an obvious limitation was the lack of objective assessment of PFD. However, an objective assessment would have been very impractical and might have led to another type of selection bias. The diagnosis of POP was mainly based on the perception of a vaginal bulge. This is particularly relevant to sPOP, as the distinction between normal and disease states is misleading and arbitrary, as POP is not a uniform, easily definable pathological condition, but rather a continuum or spectrum ranging from barely existing to clearly present. Diagnostic questions based on symptoms are therefore considered to be prone to spectrum bias. 


\section{Considerations regarding definitions and classifications}

A questionnaire with validated questions was used for the identification of the different forms of PFD. At the beginning of the project, there was no complete questionnaire for all PFDs. We created a 40-item questionnaire that contained three different validated symptom-specific instruments: Sandvik's severity index for UI, Tegerstedt's for POP, and the Jorge/Wexner severity score for AI $(155,163,164)$.

Symptom severity and degree of bothersomeness for UI and subtypes of UI are important aspects because of its mental impact and the socio-economic consequences $(82,165)$.

Self-reported symptoms may differ from clinical assessment. MUI, the most bothersome subtype of UI, occurred more frequently in women when reported in a questionnaire than when diagnosed by urodynamics $(166,167)$. This could inflate the prevalence rates reported in our study. However, Sandvik et al. have shown that even clinical assessment and urodynamics may overestimate the condition by misdiagnosing a pure SUI as MUI (167).

The Sandvik severity index used in this study is a semi-objective classification of the severity of UI, based on information collected with a postal questionnaire (163).

Symptoms of UI, if it causes bother or not, and to what degree, may be considered an essential criterion for whether the PFDs are relevant to motivate prevention and treatment (168). For this purpose, the participants were asked to answer whether or not the condition caused bother and to what extent.

Symptomatic POP was assessed using the 5-item questionnaire of Tegerstedt et al. with the key symptom "feeling of a vaginal bulge" followed by the selection of symptom frequency "Never, Infrequently, Sometimes and Often". A positive response was affirmed if the 
participant answered: "Infrequently, Sometimes, or Often". The vaginal bulge question was validated in Swedish women with mixed parity (164). They found a positive predictive value of about $60 \%$, meaning that $40 \%$ of women classified as sPOP did not have a clinical prolapse. However, the negative predictive value was $97 \%$, meaning that only $3 \%$ of women classified as not having prolapse actually had clinical prolapse. Nulliparous women are more likely to produce false-positive responses due to coexisting conditions from the vulvar/vaginal area that trigger sensations that mimic and are misinterpreted as genital prolapse. This is a typical example of a spectrum bias (169).

Childhood nocturnal enuresis was affirmed if the participant affirmed "Were you a bed-wetter in childhood?" and "At what age did it stop?". The age cut-off was set at 5 years or older, as this age is used by the DSM-5 (153).

FI was defined as accidental leakage of solid or liquid stool, with or without gas leakage. AI was defined as FI or isolated gas incontinence (IGI). Severe incontinence (FI, AI and IGI) was defined as a bothersome condition (some bother, much bother, a major problem, but not a minor nuisance) occurring several times a month or more often. It is challenging to compare prevalence rates of FI due to different cut-offs for frequency. Telephone and face-to-face interviews to collect data report lower prevalence than studies based on self-reporting symptoms from a questionnaire because of the sensitive nature of this issue $(157,159)$. It has been reported that $70-90 \%$ of women with FI are reluctant to report symptoms to their physician or to seek care (170-172). However, there is a positive association between health care seeking behavior and symptom severity. Bharucha et al reported that $48 \%$ of women with sever FI had consulted a physician for their symptoms compared to the overall rate of help-seeking in the study population of $10 \%(138)$. 


\section{Results, results in context, and comments}

\section{Paper I}

Our main findings were that urinary function in nulliparous women deteriorated during the 4 most active decades of adult life. However, $75 \%$ remained continent by age 65 , and among women with normal BMI, this was true for $>80 \%$.

Of note is the negligible number of medical interventions for UI, which occurred in only $0.3 \%$ of all nulliparous women and $2 \%$ of nulliparous women with UI.

In terms of both prevalence and severity, all aspects of urinary dysfunction increased with age, except for the number of "daytime micturition " and "other UI". The most significant increase was observed for nocturia $\geq 2$, MUI, leakage $\geq 1$ /week, leakage of more than a few drops of urine, and bothersome UI. This indicates that a significant proportion of women, with no pervious childbirth, have a dysfunctional pelvic floor.

To our knowledge, there has been no study on various aspects of UI that has examined a large population of exclusively nulliparous women of various ages. Several population-based crosssectional studies have presented nulliparas from a wide age range as a subcategory of parity (2, 173-175), but have not stratified them by age and thus cannot be used for comparison with our data. The study by Nygaard et al. (2) reported that $6.5 \%$ of nulliparous women $\geq 20$ years had UI (defined as moderate to severe incontinence according to Sandvik et al (163)). Recent studies using validated questionnaires and the ICS definition of UI reported a UI prevalence of $11-21 \%(92,176,177)$ in selected cohorts of young nulliparous women aged 20-35 years, which is consistent with the UI prevalence in our youngest age group (25-34 years). The EPINCONT study, unlike other studies, reported the prevalence of UI (any leakage) of 
nullipara for different age groups in 2001 (20). The prevalence of UI in the age group 20-34 years was $8 \%$, which is similar to our youngest group (10.1\%), considering the slightly wider downward age range in the EPINCONT study. However, their results showed no further increase in the prevalence of UI in the age group $35-44$ years $15 \%$ to $18 \%$ in the age group 45-54 years and $16 \%$ in women aged 55-64 years. In contrast, in this study, the positive correlation between advancing age and increasing prevalence of UI was positive and highly significant for linearity $(\mathrm{r}=0.86)$, indicating a large effect size. Indeed, most of the more severe forms of UI and any UI increased linearly. Linearity is important because it may facilitate a possible comparison between nullipara and women of different parity and age. Interestingly, previous studies of predominantly parous women have shown that UI prevalence increases linearly with age $(95,178,179)$.

In the present study, the prevalence proportion and progression of UI subtypes showed an interesting age-related pattern. The observed decline for isolated SUI in older women need not be explained by recovery or coping strategies alone. It is more likely due to "recruitment" into the MUI group, i.e., women who initially have isolated SUI also have urgency symptoms later. Similarly, women who initially have isolated UUI also get stress incontinence symptoms. In both cases, they would end up having MUI, which was supported by the observation that MUI showed the greatest age-related increase; this pattern of change over time has been observed previously (178).

\section{Paper II}

The main finding of our study is that sPOP prevalence was high and highest in the youngest women, and decreased with age. Conversely, the number of surgical procedures for POP was 
negligible in this cohort of nulliparous women aged 25 to 64 years. The cut-off point of symptom frequency to define a positive response had a critical impact on prevalence rates and decreased dramatically with higher frequency. In addition, the symptom "bulging" was strongly associated with the symptom "chafing" and similarly, although somewhat weaker, with the co-occurrence of FI and urgency/OAB. The proportion of co-occurring symptoms increased linearly with increasing frequency of "bulging".

In contrast to our findings, two cross-sectional studies of randomly selected US women aged $\geq 20$ years reported an sPOP prevalence of $0.6 \%$ in subgroups of nulliparous women (2). In the survey by Nygaard et al. (2), the question for sPOP was, "Do you experience bulging or something falling out that you can see or feel in the vaginal area?" Two of 396 nulliparous women admitted to this symptom. Tegerstedt et al. (122) used a postal questionnaire to determine the prevalence of POP in a survey of 5489 randomly selected women living in the city of Stockholm. Of 1458 nullipara (mean age 44 years), 35 (2.4\%) answered in the affirmative to the question "Do you have the sensation of tissue protrusion (vaginal bulge) from the vagina?" which is identical to the question used in our study (122). In a recent questionnaire study by Cooper et al. (180) from a UK community practice with women aged $>18$ years (both parous and nulliparous), two questions from the International Consultation at Incontinence Questionnaire for Vaginal Symptoms (ICIQ-VS) were used to identify POP: "Are you aware of a lump or bulge in your vagina?" and "Do you feel that a lump or bulge is coming out of your vagina so that you can feel or see it/it from the outside?". Interestingly, the prevalence was 8.4 and $4.9 \%$, respectively (180). These results suggest that the content, wording, and definition of a positive response may significantly affect the prevalence rate.

In contrast to studies based on self-report, the prevalence of prolapse based on clinical investigations has provided more consistent results. A few studies based mainly on 
convenient samples of women attending outpatient clinics have described POP-Q stages in nulliparous women of different ages. In four studies with a total of 607 nulliparous women, 3 women aged $<60$ years had POP-Q stage $\geq 3(0.5 \%)$, and $20-25 \%$ had prolapse stage $2(123$, $125,181-183)$. Because of selection bias in outpatient samples, these results are likely overestimated.

There are also case-reports of rare causes of prolapse in nulliparous women. They form a heterogeneous group with various medical conditions such as connective tissue diseases, previous pelvic surgery, undergone pelvic fractures, spinal cord injuries, persistent severe constipation, and excessive strenuous physical activity (184-187). We had no information about these conditions in the questionnaire.

The rarity of prolapse in nullipara is supported by registry data on prolapse surgery. According to the Swedish GynOp Registry (188), 278 (0.8\%) of all reconstructive prolapse procedures in the 7-year period 2010-2016 $(n=33,124)$ were performed in women who reported being nulliparous. The study by Lo et al. reported on 1275 surgically treated women with prolapse at POP-Q stage $\geq 3$. In this large sample from a Taiwanese centre collected between 2005 and 2015, 8 women were nulliparous (0.55\%) (185).

Although the relationship between clinical stage and POP symptoms is unpredictable (189), symptoms have been shown to increase markedly once the leading edge reaches $1 \mathrm{~cm}$ distal to the introitus; therefore, some patients with POP-Q stage 2 and all with stage $\geq 3$ are included (190). Tan et al. found that women with POP-Q stage 2 had symptoms $1 \mathrm{~cm}$ above the introitus in $24 \%$ and at the hymenal remnant in $49 \%$ (191). Given that stages 0 and $1(>80 \%)$ predominate in nulliparous women $(123,181-183)$ with the distribution most likely skewed toward the more proximal and asymptomatic stages $0-2$, the prevalence of symptoms due to 
anatomic prolapse in nulliparous women aged 60 years or older should theoretically not exceed $1-2 \%$.

The overall rarity of POP in nulliparous women is confirmed by the low percentage of POP operations in this group $(0.55-1.5 \%)(184,188)$, which may be explained by the absence or presence of low pelvic organ prolapse quantification (POP-Q) STAGES $(0,1$ and 2$)$ on clinical examination up to the age of 60 years (181). It is a common belief that it may take many years after childbirth for the symptoms and signs of POP to manifest themselves and for women present for examination and treatment $(192,193)$. This is supported by the observation that the surgical treatment peaks after the age of 70 (4). This long delay may be due to biological ageing or to external components, the effects of which extend over a longer period of time during which the clinical condition deteriorates and symptoms appear that affect the well-being and quality of life of the affected women $(194,195)$. This long latency period makes it difficult to determine the relative influence and timing of causative components for the onset of POP.

The relationship between POP-Q stage 0 , and the symptom of "bulging" was studied by Tegerstedt et al. $(122,164)$. In 199 women, they found that "bulging" occurred " Infrequently " in 6.0\%, "sometimes" in $2.5 \%$, and "often" in $0 \%$.

This study is a unique natural experiment and the first to report the proportion of clearly falsepositive responses in a large group of women who had no clinically detectable prolapse. In addition, their results are very similar to the result of the present study $5.1,2.4$, and $0.4 \%$ (Infrequent/sometimes/often). This similarity is significant because both Tegerstedt et al. and the present study used the same question for sPOP, analysed a randomly selected Swedish population, and were conducted within 10 years. It seems reasonable, therefore, to expect that 
both nulliparous women older than 65 years and women without anatomical prolapse selfreport that they have "bulging" ("Infrequently/Sometimes/often") $\approx 8 \%$. These data also demonstrate that the choice of symptom frequency cut-off to define a positive response is critical to prevalence rates.

In this study, the prevalence and age-related trend of sPOP were counterintuitive, suggesting a spectrum effect (196). Unlike UI and FI, genital prolapse is not a uniform, easily definable pathological condition but rather a continuum ranging from barely present to markedly present. The distinction between a normal variant and a disease state POP is considered arbitrary (197), both on the basis of clinical examination (169) and on the basis of diagnostic questions that are symptom-based and considered particularly prone to spectrum bias. In surveys with a low prevalence of the target condition, there may be more individuals in whom the condition is less severe and atypical (196), further increasing the likelihood of a spectrum effect. Nulliparous women, whose clinical stages tend to be "Non-existent" and some milder forms, might interpret the question of "bulging" differently than women with genital prolapse beyond the hymen, who experienced the disease-specific symptom often and over a long period of time. For example, in the study by Tegerstedt et al., the symptom of "bulging" was experienced "Sometimes or more often" in $85.5 \%$ of women with clinically confirmed POP and $2.5 \%$ of women with POP-Q stage 0 (164). In our study, the prevalence of sPOP, defined by the cut-off frequency that included only those who had the symptom "Sometimes or more often", was similar (2.9\%).

The puzzle of false-positive responses in women without clinical prolapse has not yet been satisfactorily investigated. If there is no prolapse, the sensation perceived as "bulging" must be due to other conditions. Asking about a bulging sensation is more likely to result in falsepositive responses if coexisting conditions at the same anatomic site produce sensations that 
mimic the classic symptom and are misinterpreted $(196,198)$. Young age $(<35)$, overweight and obesity, and enuresis were significantly but weakly associated with the " bulging" symptom. The strong association between UI and prolapse in the literature (7) was not observed in this study, further indicating that anatomical prolapse was not present. The three most robust predictors of sPOP were chafing, urgency/OAB and FI. The high prevalence of "chafing" in women in the youngest age group may be explained by their high physical and sexual activity. The association between the successive increase in prevalence and clustering of these conditions and the increasing frequency of SPOP suggests that they may contribute to the sensations perceived as "chafing" and lead to false-positive responses.

\section{Paper III}

The main finding of this study was that all parameters of lower urinary tract symptoms and incontinence were approximately twice as high in nulliparous women with a history of CNE. A wide range of lower urinary tract symptoms: UI, SUI, UUI, MUI, moderate to severe UI, UI 10 YEARS, urinary frequency $\geq 8$ /day, nocturia $\geq 2 /$ night and urgency/OAB, sPOP, FI and $\geq 1$ PFDs were more common in women with a history of CNE than in women without a history of CNE suggesting that there is at least one common causal factor linking CNE to these adult pelvic floor disorders.

The earliest studies of a possible association between CNE and PFDs in adulthood showed an association with UUI in adulthood, but not SUI $(149,150,199)$. These observations were later confirmed for UUI (OR 2.7, P 0.005) and severe UI (OR 2.9, $\mathrm{P}=0.002)$ in the study by 
Kuh et al. comprising 1333 predominantly multiparous women aged 48 years (151). In a clinical evaluation of 1021 women attending their annual gynaecological examination, Gurbuz et al. found an association between CNE and SUI and FI, but no association with MUI and UUI (148). Fitzgerald et al. showed an association with weekly or frequent UUI in adults (OR 2.7), but no association with urinary frequency $\geq 8$ /day, nocturia $\geq 2 /$ night, urinary urgency or SUI weekly and more frequently (200). D' Ancona et al. interviewed patients presenting to an outpatient clinic with UI (585 women, 76 men, mean age 54 years) and found that those with MUI and UUI in adulthood were more likely to have a history of CNE than those with SUI (147). Although preferentially focused on UI, the results of these studies were inconsistent and based on smaller, often convenient samples of women with mixed parity.

The main difference between these previous studies and the present study was that the main confounding factor for the occurrence of PFDs, caused by childbirth, was excluded by using only nulliparous women. In addition, the current study was based on a large nationwide and randomly selected cohort.

An interesting finding of this study was the relationship between CNE and sPOP and between CNE and FI and bothersome FI. There are reasons to be skeptical about the rate of sPOP in nulliparous women both with and without $\mathrm{CNE}$, due to the rarity of the condition in nulliparous women and the misdiagnosis of the "bulging" question leading to false-positive responses, as discussed earlier in Paper II. However, there is no obvious reason to reject the conclusion that the difference in prevalence between women with and without CNE reflects a genuine difference in pelvic support. 


\section{Paper IV}

The main finding of this study was that the predominant type of leakage in nulliparous women with FI was liquid stool leakage, which occurred in $>90 \%$ of cases. Solid stool leakage occurred in one in three women, of whom $\sim 80 \%$ also had leakage of liquid stool. Isolated leakage of liquid stool increased significantly in all age groups, while isolated solid stool occurred in $<0.4 \%$ overall. The distribution pattern of different types of leakage was similar in all age groups. BMI and age were interacting risk factors for FI.

There is limited information in the literature on FI in adult 0-para women. In a Norwegian survey of 1448 (predominantly rural) 0 -para women aged $\geq 30$ years, FI was found in $3.0 \%$ and $\mathrm{AI}$ in $17.3 \%$, of which $>97 \%$ had gas incontinence (201). A Danish study surveyed 1375 non-pregnant 0 -para (mean age 26 years) from the catchment area of Copenhagen University Hospital (202). The rate of leakage of solid stool was $2.5 \%$, similar to the probability of leakage of solid stool at age 25 years in this study, which was $3.3 \%$. Th probability of liquid stool leakage more than doubled from $8.1 \%$ to $19.2 \%$ at age 25 years in this study. The likely explanation for this discrepancy is that the Danish cohort was younger and more metropolitan. In a Dutch survey of 291 nullipara (mean $\sim 40$ years), $7.2 \%$ had FI, comparable to the FI probability of $11.6 \%$ at age 40 in this report (203).Varma et al. described 385 nullipara aged 40-69 years, who had FI in 20\% (204), comparable to a probability of $16 \%$ at age 60 in this study. Most previous studies were small or used convenience samples from hospitals and regional surveys, limiting comparison with our results. This study is the first to describe FI over four decades in a randomly selected large national cohort. 
Two recent systematic reviews have summarized information on the prevalence and risk factors for FI among women living in the community $(80,132)$. In three studies with representative samples, the median prevalence of FI was $11.2 \%(80)$. The mean prevalence in the surveys reviewed by Sharma et al. was $\sim 12 \%$ (132). These results agree well with the finding of this study (11.8\%). There are many causes of involuntary stool and gas leakage that originate in the intestinal tract or posterior compartment of the pelvic floor $(205,206)$. The differences reported in the literature regarding measures of bowel incontinence, presentation, frequency of leakage, co-occurring symptoms, the timeline, and various aspects of impact do not point to a specific causal component $(206,207)$. These reported differences pose a challenge to research on the relationships between incontinence and birth-related injuries. Although liquid stool per se is pathognomonic for some form of bowel dysfunction, its presence in women with FI does not preclude a concomitant sphincter dysfunction that lowers the threshold for leakage (132). Involuntary anal leakage may also occur despite a completely intact continence mechanism (205).

Many population-based studies of community-dwelling women have identified IBS and diarrhoea as major risk factors for FI $(141,170,208,209)$. The global prevalence of IBS is estimated to be $\sim 11 \%(210,211)$, and is twice as common in women than in men (212). Thus, the prevalence in women is almost $15 \%$. Furthermore, unlike women, FI in men is predominantly due to impaired rectal sensation and disturbances of evacuation (213). In 15$20 \%$, IBS overlaps with FI $(214,215)$. It seems reasonable to assume that 0-para women should resemble women in the general population in terms of various enteric risk factors for FI. In a recent cohort study on FI in IBS patients, diarrhoea according to the Rome III criteria (216), occurred in $\sim 85 \%$, similar to our finding for leakage of liquid stool in more than $90 \%$. The combination of solid and liquid stool leakage, a typical feature of IBS, was noted in 
$\sim 40 \%$ (214). Likewise, women in this study, had combined solid and liquid stool leakage in $\sim 30 \%$.

Age is the most commonly reported risk factor for FI, as summarized by $\mathrm{Ng}$ et al (80). In our study, age was a risk factor for FI and severe FI (both $\mathrm{P}<0.0001$ ). The incidence of FI and severe FI appeared to plateau at ages up to 45 and over 50 years, with an apparent increase in incidence between 40 and 50 years. A similar pattern was described by Simrén et al. in IBS patients with FI (214). While FI is widely recognized as common in the elderly and associated with frailty and multiple comorbidities (217), we found that FI even in the absence of childbirth, increased already from age 25 .

We also found that increasing BMI was significantly associated with FI $(\mathrm{P}<.0001)$. Currently, there are only a few conflicting studies on the effect of BMI on FI $(81,140,201,218)$. Obesity is potentially associated with FI through many pathways. Obesity is associated with diarrhoea, which may be caused by diabetes and its medications, excessive intake of low fibre diet, and bile acid diarrhoea after cholecystectomy (78). Diarrhoea occurs in 5-35\% of diabetics, and diarrhoea was the strongest risk factor for FI identified in several populationbased studies (80).

Leakage of solid faeces is considered a critical measure of incontinence in some scenarios. Colorectal surgeons consider solid stool leakage to be the singular most important component of FI, as it directly reflects the integrity of the anal continence mechanism and serves as an important tool in assessing the outcome of sphincter reconstructive surgery. In epidemiology, incontinence to solid faeces is a decisive measure of an obstetric anal sphincter injury (OASI) (207). In population-based studies, constipation and solid stool were among the three most commonly reported factors not associated with FI (80). This is consistent with our findings 
showing an overall rate of solid stool leakage of $<0.4 \%$. In addition to childbirth, other events may directly compromise the continence mechanism. These include perineal sepsis with abscess and fistula formation and subsequent surgery, sphincterotomy, failed haemorrhoidectomies, and neurogenic or mechanical trauma, but these are all rare in community-dwelling women (79). This was supported in a representative cohort study of 1610 Swedish citizens where leakage of solid stool occurred in $1.4 \%$ of women and $0.4 \%$ of men (219). In an Irish study on 0-para women at 15- weeks' gestation, 1.2\% reported FI with normal stool (121). In IBS patients seeking care at primary and tertiary care facilities (both genders), FI occurred in $6 \%$ of those with constipation according to Rome III criteria (214, 220).

In this study, liquid stool and gas leakage dominated. Concomitant leakage of "solid" and "liquid" stool was common, and isolated leakage of solid stool was negligible, suggesting that FI was most likely caused by IBS. The similarity in the distribution of the different presentations of leakage between all age groups and the fact that FI was prevalent among the youngest 0 -para, also suggests that FI was caused by the same condition across ages. It will therefore be difficult to determine the impact of OASI on FI in population-based studies due to these highly prevalent and strong confounding factors such as IBS, age, BMI, and other prevalent factors, e.g., eating habits, smoking, and diabetes, that may trigger liquid stool and diarrhoea (ref). This most likely explains why, in the 10 studies reviewed by $\mathrm{Ng}$ et al, obstetric history or previous obstetric trauma were among the three most commonly reported factors not associated with FI (80). To determine whether or not OASI is a risk factor for FI, we propose to increase the accuracy of studies by limiting the study population to vaginally delivered women matched for parity, with and without a history of sphincter injury $(67,221)$. 


\section{Conclusions}

1. Over a time-span of 40 years starting at the age of 25 , the prevalence of virtually all UI parameters increased. By age 55-64 years, every fourth nulliparous woman had developed UI. This suggests that the female pelvic floor is inherently vulnerable and prone to developing functional disorders.

2. The prevalence of SPOP in nulliparous women reported in this study was higher than in most previous reports. The symptom "bulging" was strongly associated with the symptom "chafing." The number of surgical procedures for prolapse was negligible in this cohort of nulliparous women aged 25 to 64 years suggesting that genital prolapse is rare in nulliparous women. The inflation of our results could be due to the predominance of weak and infrequent symptoms and the clustering of other conditions mimicking sPOP.

3. The various forms of PFD and lower urinary tract symptoms in nulliparous women were approximately doubled in nulliparous women with a history of CNE. Therefore, CNE was a significant predictor of a wide range of PFD, indicating the possible existence of at least one common causal factor linking CNE to late PFD in nullipara aged 25-64 years. 
4. FI was prevalent in women unaffected by childbirth and was almost exclusively linked to symptoms of enteric dysfunction, with a pattern similar to that in IBS. The contribution of a failing pelvic continence mechanism seemed to be negligible. 


\section{Acknowledgement}

My special thanks to all the women who have enriched our knowledge by generously giving their time and participating in this study.

I would like to thank everyone who helped me throughout this dissertation. In particular I would like to thank:

Associate Professor Maria Gyhagen: My main supervisor, who guided me through this research with her expertise and knowledgeable guidance. Her enthusiasm, patience and support gave me the tools I needed to successfully complete my dissertation. Thank you for always being available, generous, and attentive.

Professor Ian Milsom: Assistant supervisor and co-author, for sharing his vast knowledge, for his generosity and for giving me the opportunity to further my research.

Sigvard Åkervall: Mentor and co-author, for his invaluable guidance throughout my research education. His insightful feedback and enthusiasm pushed me to sharpen my thinking and take my work to a higher level.

Mattias Molin: for his statistical expertise and valuable suggestions in handling the analytical statistics.

Ida Nilsson and Jenny Larsudd-Kåverud: co-authors and friends for their insightful advice and support.

Lars-Åke Mattsson, Claes Magnusson and Sofia Sjöström: for their valuable feedback at my half-time seminar

Lotta Wassén, Corinne Pedroletti and Helena Hognert: Heads of the Department of Gynecology, at Sahlgrenska University Hospital for their encouragement and support and for releasing me from clinical work to conduct my study.

Anja Andersson: for her administrative help and friendly chat

My colleagues in the Department of Obstetrics and Gynecology, Sahlgrenska University Hospital and especially the Urogynecology team for all their motivation and support. Special thanks to my friends and colleagues Rim Berggren, Emma Rosenberg, Caroline Stadelmann and Sofiia Karlsson for their encouragement and for our regular meetings that made everything brighter and more bearable.

Tagrid Jar-Allah: Best friend and colleague who supported me and put up with my worries and moans during writing my dissertation. 
My parents (Vian and Ghazwan) who set me on the path to this PhD long ago, for their endless and unconditional love and support all these years.

My mother-in-law (Faheema) who has repeatedly flown all the way from Iraq to selflessly help me during difficult times

My brothers Omar and Ali for their love and encouragement and the valuable and stimulating discussions we always have.

Sarbaz, my wonderful husband, who motivated and encouraged me to take this step, stood by me and supported me in every possible way to achieve my goal.

Lara, Rawan and Alan, my children, for all the love they showed me even when in times I was grumpier than usual.

The Sahlgrenska University Hospital LUA/ALF and the Hjalmar Svensson Research

Foundation for the generous financial support during the work on this thesis 


\section{References}

1. Milsom I AD, Cartwright R, Lapitan MC, Nelson R, Sillén U, Tikkinen K. Epidemiology of urinary incontinence (UI) and other lower urinary tract symptoms (LUTS), pelvic organ prolapse (POP) and anal incontinence (AI). In: Abrams P CL, Wagg A, Wein A, editor. Incontinence. 6th ed. Paris: Health Publications Ltd; 2017. p. 5-16.

2. Nygaard I, Barber MD, Burgio KL, Kenton K, Meikle S, Schaffer J, et al. Prevalence of symptomatic pelvic floor disorders in US women. JAMA. 2008;300(11):13116. 3. de Boer TA, Slieker-Ten Hove MC, Burger CW, Kluivers KB, Vierhout ME. The prevalence and factors associated with previous surgery for pelvic organ prolapse and/or urinary incontinence in a cross-sectional study in The Netherlands. Eur J Obstet Gynecol Reprod Biol. 2011;158(2):343-9.

4. $\mathrm{Wu}$ JM, Matthews CA, Conover MM, Pate V, Jonsson Funk M. Lifetime risk of stress urinary incontinence or pelvic organ prolapse surgery. Obstet Gynecol. 2014;123(6):1201-6.

5. Smith FJ, Holman CD, Moorin RE, Tsokos N. Lifetime risk of undergoing surgery for pelvic organ prolapse. Obstet Gynecol. 2010;116(5):1096-100.

6. Gyhagen M, Åkervall S, Milsom I. Clustering of pelvic floor disorders 20 years after one vaginal or one cesarean birth. Int Urogynecol J. 2015;26(8):1115-21.

7. Gyhagen M, Bullarbo M, Nielsen TF, Milsom I. Prevalence and risk factors for pelvic organ prolapse 20 years after childbirth: a national cohort study in singleton primiparae after vaginal or caesarean delivery. BJOG. 2013;120(2):152-60. 
8.

Milsom I, Altman D, Cartwright R, Lapitan M, Nelson R, Sillén U, et al.

Epidemiology of urinary incontinence (UI) and other lower urinary tract symptoms (LUTS), pelvic organ prolapse (POP) and anal incontinence (AI). Incontinence: 5th International Consultation on Incontinence, Paris, February 2012: ICUD-EAU; 2013. p. 15-107.

9. $\mathrm{Wu}$ JM, Hundley AF, Fulton RG, Myers ER. Forecasting the prevalence of pelvic floor disorders in U.S. Women: 2010 to 2050. Obstet Gynecol. 2009;114(6):1278-83. 10. Wagner T, Moore K, Subak L, De Wachter S, Dudding T. Economics of urinary and faecal incontinence, and prolapse. Incontinence. 2017;2:2479-512.

11. Ekelund P, Grimby A, Milsom I. Urinary incontinence. Social and financial costs high. BMJ: British Medical Journal. 1993;306(6888):1344.

12. Ford AA, Rogerson L, Cody JD, Aluko P, Ogah JA. Mid-urethral sling operations for stress urinary incontinence in women. Cochrane Database Syst Rev. 2017;7:CD006375.

13. Karmakar D, Mostafa A, Abdel-Fattah M. Long-term outcomes of transobturator tapes in women with stress urinary incontinence: E-TOT randomised controlled trial. BJOG. 2017;124(6):973-81.

14. Olsen AL, Smith VJ, Bergstrom JO, Colling JC, Clark AL. Epidemiology of surgically managed pelvic organ prolapse and urinary incontinence. Obstet Gynecol. 1997;89(4):501-6.

15. Benson JT, Lucente V, McClellan E. Vaginal versus abdominal reconstructive surgery for the treatment of pelvic support defects: a prospective randomized study with longterm outcome evaluation. Am J Obstet Gynecol. 1996;175(6):1418-21; discussion 21-2.

16. Diwadkar GB, Barber MD, Feiner B, Maher C, Jelovsek JE. Complication and reoperation rates after apical vaginal prolapse surgical repair: a systematic review. Obstet Gynecol. 2009;113(2 Pt 1):367-73. 
68 Pelvic Floor Dysfunction in Nulliparous Women

17. Denman MA, Gregory WT, Boyles SH, Smith V, Edwards SR, Clark AL.

Reoperation 10 years after surgically managed pelvic organ prolapse and urinary incontinence. Am J Obstet Gynecol. 2008;198(5):555 e1-5.

18. Bergman I. Rekonstruktiv Bäckenbottenkirurgi Sweden: Gynop Register; 2020.

19. Person B, Wexner SD. Advances in the surgical treatment of fecal incontinence. Surg Innov. 2005;12(1):7-21.

20. Rortveit G, Hannestad YS, Daltveit AK, Hunskaar S. Age- and type-dependent effects of parity on urinary incontinence: the Norwegian EPINCONT study. Obstet Gynecol. 2001;98(6):1004-10.

21. MacLennan AH, Taylor AW, Wilson DH, Wilson D. The prevalence of pelvic floor disorders and their relationship to gender, age, parity and mode of delivery. BJOG. 2000;107(12):1460-70.

22. Howard D, Delancey JO, Tunn R, Ashton-Miller JA. Racial differences in the structure and function of the stress urinary continence mechanism. Obstet Gynecol. 2000;95(5):713-7.

23. Sampselle CM, Miller JM, Mims BL, Delancey JO, Ashton-Miller JA, Antonakos CL. Effect of pelvic muscle exercise on transient incontinence during pregnancy and after birth. Obstet Gynecol. 1998;91(3):406-12.

24. Wei JT, De Lancey JO. Functional anatomy of the pelvic floor and lower urinary tract. Clin Obstet Gynecol. 2004;47(1):3-17.

25. DeLancey JO. Anatomic aspects of vaginal eversion after hysterectomy. Am J Obstet Gynecol. 1992;166(6 Pt 1):1717-24.

26. Floyd WF, Walls EW. Electromyography of the sphincter ani externus in man. J Physiol. 1953;122(3):599-609. 
MM, Alshiek J, Shoebeiri A, Sultan AH, editor. Pelvic Floor Disorders: Springer; 2021. p. 24-45.

28. Lestar B, Penninckx F, Kerremans R. The composition of anal basal pressure. International Journal of Colorectal Disease. 1989;4(2):118-22.

29. Bharucha AE. Pelvic floor: anatomy and function. Neurogastroenterol Motil. 2006;18(7):507-19.

30. Raizada V, Bhargava V, Karsten A, Mittal RK. Functional morphology of anal sphincter complex unveiled by high definition anal manometery and three dimensional ultrasound imaging. Neurogastroenterol Motil. 2011;23(11):1013-9, e460.

31. Shobeiri SA, Chesson RR, Gasser RF. The internal innervation and morphology of the human female levator ani muscle. Am J Obstet Gynecol. 2008;199(6):686 e1-6. 32. Petros PE, Ulmsten UI. An integral theory of female urinary incontinence. Experimental and clinical considerations. Acta Obstet Gynecol Scand Suppl. 1990;153:7-31. 33. DeLancey JO. The pathophysiology of stress urinary incontinence in women and its implications for surgical treatment. World J Urol. 1997;15(5):268-74.

34. M. Swash PP. The Pelvic Floor: Neurocontrol and Functional Concepts. In: W. A. Santoro GA WM, Alshiek J, Shoebeiri A, Sultan AH, editor. Pelvic Floor Disorders2021. p. $57-70$.

35. Steers WD. Pathophysiology of overactive bladder and urge urinary incontinence. Rev Urol. 2002;4 Suppl 4(Suppl 4):S7-s18.

36. Perucchini D, DeLancey JO, Ashton-Miller JA, Galecki A, Schaer GN. Age effects on urethral striated muscle. II. Anatomic location of muscle loss. Am J Obstet Gynecol. 2002;186(3):356-60. 
70 Pelvic Floor Dysfunction in Nulliparous Women

37. Robinson D, Cardozo LD. The role of estrogens in female lower urinary tract dysfunction. Urology. 2003;62(4 Suppl 1):45-51.

38. Trowbridge ER, Wei JT, Fenner DE, Ashton-Miller JA, Delancey JO. Effects of aging on lower urinary tract and pelvic floor function in nulliparous women. Obstet Gynecol. 2007;109(3):715-20.

39. Alperin M, Cook M, Tuttle LJ, Esparza MC, Lieber RL. Impact of vaginal parity and aging on the architectural design of pelvic floor muscles. Am J Obstet Gynecol. 2016;215(3):312.e1-9.

40. Nordling J. The aging bladder--a significant but underestimated role in the development of lower urinary tract symptoms. Exp Gerontol. 2002;37(8-9):991-9.

41. Hunskaar S, Arnold EP, Burgio K, Diokno AC, Herzog AR, Mallett VT. Epidemiology and natural history of urinary incontinence. Int Urogynecol J Pelvic Floor Dysfunct. 2000;11(5):301-19.

42. Danforth KN, Townsend MK, Lifford K, Curhan GC, Resnick NM, Grodstein F. Risk factors for urinary incontinence among middle-aged women. Am J Obstet Gynecol. 2006;194(2):339-45.

43. Noblett KL, Jensen JK, Ostergard DR. The relationship of body mass index to intra-abdominal pressure as measured by multichannel cystometry. Int Urogynecol J Pelvic Floor Dysfunct. 1997;8(6):323-6.

44. Santaniello F, Giannantoni A, Cochetti G, Zucchi A, Costantini E. Body mass index and lower urinary tract symptoms in women. Arch Ital Urol Androl. 2007;79(1):17-9. 45. Han MO, Lee NY, Park HS. Abdominal obesity is associated with stress urinary incontinence in Korean women. Int Urogynecol J Pelvic Floor Dysfunct. 2006;17(1):35-9. 
46.

Bai SW, Kang JY, Rha KH, Lee MS, Kim JY, Park KH. Relationship of

urodynamic parameters and obesity in women with stress urinary incontinence. J Reprod Med. 2002;47(7):559-63.

Åkervall S, Al-Mukhtar Othman J, Molin M, Gyhagen M. Symptomatic pelvic organ prolapse in middle-aged women: a national matched cohort study on the influence of childbirth. Am J Obstet Gynecol. 2020;222(4):356.e1-.e14.

48. Mant J, Painter R, Vessey M. Epidemiology of genital prolapse: observations from the Oxford Family Planning Association Study. Br J Obstet Gynaecol. 1997;104(5):57985.

49. Lien KC, Mooney B, DeLancey JO, Ashton-Miller JA. Levator ani muscle stretch induced by simulated vaginal birth. Obstet Gynecol. 2004;103(1):31-40. 50. Lien KC, Morgan DM, Delancey JO, Ashton-Miller JA. Pudendal nerve stretch during vaginal birth: a 3D computer simulation. Am J Obstet Gynecol. 2005;192(5):1669-76. 51. Chiaffarino F, Chatenoud L, Dindelli M, Meschia M, Buonaguidi A, Amicarelli F, et al. Reproductive factors, family history, occupation and risk of urogenital prolapse. Eur J Obstet Gynecol Reprod Biol. 1999;82(1):63-7.

52. Jack GS, Nikolova G, Vilain E, Raz S, Rodríguez LV. Familial transmission of genitovaginal prolapse. Int Urogynecol J Pelvic Floor Dysfunct. 2006;17(5):498-501. 53. Allen-Brady K, Cannon-Albright L, Farnham JM, Teerlink C, Vierhout ME, van Kempen LCL, et al. Identification of six loci associated with pelvic organ prolapse using genome-wide association analysis. Obstet Gynecol. 2011;118(6):1345-53.

54. Nikolova G, Lee H, Berkovitz S, Nelson S, Sinsheimer J, Vilain E, et al. Sequence variant in the laminin gammal (LAMC1) gene associated with familial pelvic organ prolapse. Hum Genet. 2007;120(6):847-56. 
72 Pelvic Floor Dysfunction in Nulliparous Women

55. Cartwright R, Kirby AC, Tikkinen KA, Mangera A, Thiagamoorthy G, Rajan P, et al. Systematic review and metaanalysis of genetic association studies of urinary symptoms and prolapse in women. Am J Obstet Gynecol. 2015;212(2):199.e1-24.

56. Risk factors for genital prolapse in non-hysterectomized women around menopause. Results from a large cross-sectional study in menopausal clinics in Italy. Progetto Menopausa Italia Study Group. Eur J Obstet Gynecol Reprod Biol. 2000;93(2):135-40.

57. Hendrix SL, Clark A, Nygaard I, Aragaki A, Barnabei V, McTiernan A. Pelvic organ prolapse in the Women's Health Initiative: gravity and gravidity. Am J Obstet Gynecol. 2002;186(6):1160-6.

58. Pandey S, Bhattacharya S. Impact of obesity on gynecology. Womens Health (Lond). 2010;6(1):107-17.

59. Washington BB, Erekson EA, Kassis NC, Myers DL. The association between obesity and stage II or greater prolapse. Am J Obstet Gynecol. 2010;202(5):503.e1-4.

60. Spence-Jones C, Kamm MA, Henry MM, Hudson CN. Bowel dysfunction: a pathogenic factor in uterovaginal prolapse and urinary stress incontinence. Br J Obstet Gynaecol. 1994;101(2):147-52.

61. Forsgren C, Lundholm C, Johansson AL, Cnattingius S, Zetterström J, Altman D. Vaginal hysterectomy and risk of pelvic organ prolapse and stress urinary incontinence surgery. Int Urogynecol J. 2012;23(1):43-8.

Altman D, Falconer C, Cnattingius S, Granath F. Pelvic organ prolapse surgery following hysterectomy on benign indications. Am J Obstet Gynecol. 2008;198(5):572.e1-6. 63. Schiller LR. Faecal incontinence. Clin Gastroenterol. 1986;15(3):687-704. 64. Denis P, Colin R, Galmiche JP, Geffroy Y, Hecketsweiler P, Lefrancois R, et al. Elastic properties of the rectal wall in normal adults and in the patients with ulcerative colitis. Gastroenterology. 1979;77(1):45-8. 
65. Suzuki H, Fujioka M. Rectal pressure and rectal compliance in ulcerative colitis. Jpn J Surg. 1982;12(1):79-81.

66. Varma JS, Smith AN, Busuttil A. Correlation of clinical and manometric abnormalities of rectal function following chronic radiation injury. Br J Surg. 1985;72(11):875-8.

67. Nilsson IE, Åkervall S, Molin M, Milsom I, Gyhagen M. Symptoms of fecal incontinence two decades after no, one, or two obstetrical anal sphincter injuries. American Journal of Obstetrics and Gynecology. 2021;224(3):276. e1-. e23.

68. Snooks SJ, Setchell M, Swash M, Henry MM. Injury to innervation of pelvic floor sphincter musculature in childbirth. Lancet. 1984;2(8402):546-50.

69. Snooks SJ, Henry MM, Swash M. Faecal incontinence due to external anal sphincter division in childbirth is associated with damage to the innervation of the pelvic floor musculature: a double pathology. Br J Obstet Gynaecol. 1985;92(8):824-8.

70. Lubowski DZ, Swash M, Nicholls RJ, Henry MM. Increase in pudendal nerve terminal motor latency with defaecation straining. Br J Surg. 1988;75(11):1095-7.

71. Laurberg S, Swash M. Effects of aging on the anorectal sphincters and their innervation. Dis Colon Rectum. 1989;32(9):737-42.

72. Olsen AL, Rao SS. Clinical neurophysiology and electrodiagnostic testing of the pelvic floor. Gastroenterol Clin North Am. 2001;30(1):33-54, v-vi.

73. Beets-Tan RG, Morren GL, Beets GL, Kessels AG, el Naggar K, Lemaire E, et al. Measurement of anal sphincter muscles: endoanal US, endoanal MR imaging, or phasedarray MR imaging? A study with healthy volunteers. Radiology. 2001;220(1):81-9.

74. Bannister JJ, Abouzekry L, Read NW. Effect of aging on anorectal function. Gut. 1987;28(3):353-7. 
74 Pelvic Floor Dysfunction in Nulliparous Women

75.

Fox JC, Fletcher JG, Zinsmeister AR, Seide B, Riederer SJ, Bharucha AE.

Effect of aging on anorectal and pelvic floor functions in females. Dis Colon Rectum. 2006;49(11):1726-35.

76. Jameson JS, Chia YW, Kamm MA, Speakman CT, Chye YH, Henry MM.

Effect of age, sex and parity on anorectal function. Br J Surg. 1994;81(11):1689-92.

77.

Poylin V, Serrot FJ, Madoff RD, Ikramuddin S, Mellgren A, Lowry AC, et al.

Obesity and bariatric surgery: a systematic review of associations with defecatory dysfunction. Colorectal Dis. 2011;13(6):e92-103.

78. Markland AD, Richter HE, Burgio KL, Bragg C, Hernandez AL, Subak LL. Fecal incontinence in obese women with urinary incontinence: prevalence and role of dietary fiber intake. Am J Obstet Gynecol. 2009;200(5):566.e1-6.

79. Salvatore S DJ, Igawa Y, et al. Pathophysiology of urinary incontinence (UI), pelvic organ prolapse (POP) and faecal incontinence (FI). In: Abrams P CL, Wagg A, Wein A, editor. Incontinence. 6th ed. Paris: Health publications Ltd; 2016. p. 413-19. 80. Ng KS, Sivakumaran Y, Nassar N, Gladman MA. Fecal Incontinence: Community Prevalence and Associated Factors--A Systematic Review. Dis Colon Rectum. 2015;58(12):1194-209.

81. Altman D, Falconer C, Rossner S, Melin I. The risk of anal incontinence in obese women. Int Urogynecol J Pelvic Floor Dysfunct. 2007;18(11):1283-9. Milsom I CR, Lapitan MC, Nelson R, Sillén U, Tikkinen K. Epidemiology of Urinary (UI) and Faecal (FI) Incontinence and Pelvic Organ Prolapse (POP). In: Abrams P CL, Wagg A, Wein A, editor. Inctontinence 6th Edition: Health Publications Ltd; 2017. p. 15107.

83. Von Gontard A, Hollmann E. Comorbidity of functional urinary incontinence and encopresis: somatic and behavioral associations. J Urol. 2004;171(6 Pt 2):2644-7. 
84.

Nevéus T, Hetta J, Cnattingius S, Tuvemo T, Läckgren G, Olsson U, et al.

Depth of sleep and sleep habits among enuretic and incontinent children. Acta paediatrica. 1999;88(7):748-52.

85. Hunsballe JM. Increased delta component in computerized sleep

electroencephalographic analysis suggests abnormally deep sleep in primary

monosymptomatic nocturnal enuresis. Scandinavian journal of urology and nephrology. 2000;34(5):294-302.

86. Chandra M, Saharia R, Hill V, Shi Q. Prevalence of diurnal voiding symptoms and difficult arousal from sleep in children with nocturnal enuresis. J Urol. 2004;172(1):3116.

87. Mota DM, Barros AJ, Matijasevich A, Santos IS. Prevalence of enuresis and urinary symptoms at age 7 years in the 2004 birth cohort from Pelotas, Brazil. J Pediatr (Rio J). 2015;91(1):52-8.

88. Sureshkumar P, Jones M, Caldwell PH, Craig JC. Risk factors for nocturnal enuresis in school-age children. The Journal of urology. 2009;182(6):2893-9.

89. Loening-Baucke V. Urinary incontinence and urinary tract infection and their resolution with treatment of chronic constipation of childhood. Pediatrics. 1997;100(2 Pt 1):228-32.

90. Milsom I, Coyne KS, Nicholson S, Kvasz M, Chen CI, Wein AJ. Global prevalence and economic burden of urgency urinary incontinence: a systematic review. Eur Urol. 2014;65(1):79-95.

91. Hannestad YS, Rortveit G, Sandvik H, Hunskaar S. A community-based epidemiological survey of female urinary incontinence: the Norwegian EPINCONT study. Epidemiology of Incontinence in the County of Nord-Trøndelag. J Clin Epidemiol. 2000;53(11):1150-7. 
76 Pelvic Floor Dysfunction in Nulliparous Women

92. Brown SJ, Donath S, MacArthur C, McDonald EA, Krastev AH. Urinary

incontinence in nulliparous women before and during pregnancy: prevalence, incidence, and associated risk factors. Int Urogynecol J. 2010;21(2):193-202.

93. Peyrat L, Haillot O, Bruyere F, Boutin JM, Bertrand P, Lanson Y. Prevalence and risk factors of urinary incontinence in young and middle-aged women. BJU Int. 2002;89(1):61-6.

94.

Alnaif B, Drutz HP. The prevalence of urinary and fecal incontinence in

Canadian secondary school teenage girls: questionnaire study and review of the literature. Int Urogynecol J Pelvic Floor Dysfunct. 2001;12(2):134-7; discussion8.

95. Milsom I, Ekelund P, Molander U, Arvidsson L, Areskoug B. The influence of age, parity, oral contraception, hysterectomy and menopause on the prevalence of urinary incontinence in women. J Urol. 1993;149(6):1459-62.

96. Hunskaar S. A systematic review of overweight and obesity as risk factors and targets for clinical intervention for urinary incontinence in women. Neurourol Urodyn. 2008;27(8):749-57.

97. Subak LL, Richter HE, Hunskaar S. Obesity and urinary incontinence:

epidemiology and clinical research update. J Urol. 2009;182(6 Suppl):S2-7.

98. Chiarelli P, Brown W, McElduff P. Leaking urine: prevalence and associated factors in Australian women. Neurourol Urodyn. 1999;18(6):567-77.

99. Dallosso HM, McGrother CW, Matthews RJ, Donaldson MM. The association of diet and other lifestyle factors with overactive bladder and stress incontinence: a longitudinal study in women. BJU Int. 2003;92(1):69-77.

100. Mishra GD, Cardozo L, Kuh D. Menopausal transition and the risk of urinary incontinence: results from a British prospective cohort. BJU Int. 2010;106(8):1170-5. 
101. Waetjen LE, Liao S, Johnson WO, Sampselle CM, Sternfield B, Harlow SD, et al. Factors associated with prevalent and incident urinary incontinence in a cohort of midlife women: a longitudinal analysis of data: study of women's health across the nation. Am J Epidemiol. 2007;165(3):309-18.

102. Townsend MK, Danforth KN, Rosner B, Curhan GC, Resnick NM, Grodstein F. Body mass index, weight gain, and incident urinary incontinence in middle-aged women. Obstet Gynecol. 2007;110(2 Pt 1):346-53.

103. Brown JS, Grady D, Ouslander JG, Herzog AR, Varner RE, Posner SF. Prevalence of urinary incontinence and associated risk factors in postmenopausal women. Heart \& Estrogen/Progestin Replacement Study (HERS) Research Group. Obstet Gynecol. 1999;94(1):66-70.

104. Link CL, Steers WD, Kusek JW, McKinlay JB. The association of adiposity and overactive bladder appears to differ by gender: results from the Boston Area Community Health survey. J Urol. 2011;185(3):955-63.

105. Kim IH, Chun H, Kwon JW. Gender differences in the effect of obesity on chronic diseases among the elderly Koreans. J Korean Med Sci. 2011;26(2):250-7.

106. Bump RC, Sugerman HJ, Fantl JA, McClish DK. Obesity and lower urinary tract function in women: effect of surgically induced weight loss. Am J Obstet Gynecol. 1992;167(2):392-7; discussion 7-9.

107. Subak LL, Whitcomb E, Shen H, Saxton J, Vittinghoff E, Brown JS. Weight loss: a novel and effective treatment for urinary incontinence. J Urol. 2005;174(1):190-5. 108. Subak LL, Wing R, West DS, Franklin F, Vittinghoff E, Creasman JM, et al. Weight loss to treat urinary incontinence in overweight and obese women. N Engl J Med. 2009;360(5):481-90. 
78 Pelvic Floor Dysfunction in Nulliparous Women

109. Wing RR, West DS, Grady D, Creasman JM, Richter HE, Myers D, et al. Effect of weight loss on urinary incontinence in overweight and obese women: results at 12 and 18 months. J Urol. 2010;184(3):1005-10.

110. Press JZ, Klein MC, Kaczorowski J, Liston RM, von Dadelszen P. Does cesarean section reduce postpartum urinary incontinence? A systematic review. Birth. 2007;34(3):228-37.

111. Gyhagen M, Bullarbo M, Nielsen TF, Milsom I. The prevalence of urinary incontinence 20 years after childbirth: a national cohort study in singleton primiparae after vaginal or caesarean delivery. BJOG. 2013;120(2):144-51.

112. Gyhagen M, Bullarbo M, Nielsen TF, Milsom I. A comparison of the long-term consequences of vaginal delivery versus caesarean section on the prevalence, severity and bothersomeness of urinary incontinence subtypes: a national cohort study in primiparous women. Bjog. 2013;120(12):1548-55.

113. Fritel X, Fauconnier A, Levet C, Bénifla JL. Stress urinary incontinence 4 years after the first delivery: a retrospective cohort survey. Acta Obstet Gynecol Scand. 2004;83(10):941-5.

114. Foldspang A, Hvidman L, Mommsen S, Nielsen JB. Risk of postpartum urinary incontinence associated with pregnancy and mode of delivery. Acta Obstet Gynecol Scand. 2004;83(10):923-7.

115. Mørkved S, Bø K. Prevalence of urinary incontinence during pregnancy and postpartum. Int Urogynecol J Pelvic Floor Dysfunct. 1999;10(6):394-8.

116. Jansson MH, Franzén K, Tegerstedt G, Hiyoshi A, Nilsson K. Stress and urgency urinary incontinence one year after a first birth-prevalence and risk factors. A prospective cohort study. Acta Obstet Gynecol Scand. 2021. 
117. Hendrix SL, Cochrane BB, Nygaard IE, Handa VL, Barnabei VM, Iglesia C, et al. Effects of estrogen with and without progestin on urinary incontinence. Jama. 2005;293(8):935-48.

118. Cody JD, Richardson K, Moehrer B, Hextall A, Glazener CM. Oestrogen therapy for urinary incontinence in post-menopausal women. Cochrane Database Syst Rev. 2009(4):Cd001405.

119. Maher C, Feiner B, Baessler K, Schmid C. Surgical management of pelvic organ prolapse in women. Cochrane Database Syst Rev. 2013(4):Cd004014.

120. Walker GJ, Gunasekera P. Pelvic organ prolapse and incontinence in developing countries: review of prevalence and risk factors. Int Urogynecol J. 2011;22(2):127-35.

121. Durnea CM, Khashan AS, Kenny LC, Tabirca SS, O'Reilly BA. An insight into pelvic floor status in nulliparous women. Int Urogynecol J. 2014;25(3):337-45.

122. Tegerstedt G, Maehle-Schmidt M, Nyrén O, Hammarström M. Prevalence of symptomatic pelvic organ prolapse in a Swedish population. Int Urogynecol J Pelvic Floor Dysfunct. 2005;16(6):497-503.

123. O'Boyle AL, Woodman PJ, O'Boyle JD, Davis GD, Swift SE. Pelvic organ support in nulliparous pregnant and nonpregnant women: a case control study. Am J Obstet Gynecol. 2002;187(1):99-102.

124. Rortveit G, Brown JS, Thom DH, Van Den Eeden SK, Creasman JM, Subak LL. Symptomatic pelvic organ prolapse: prevalence and risk factors in a population-based, racially diverse cohort. Obstet Gynecol. 2007;109(6):1396-403.

125. Swift SE, Pound T, Dias JK. Case-control study of etiologic factors in the development of severe pelvic organ prolapse. Int Urogynecol J Pelvic Floor Dysfunct. 2001;12(3):187-92. 
80 Pelvic Floor Dysfunction in Nulliparous Women

126. Tegerstedt G, Miedel A, Maehle-Schmidt M, Nyrén O, Hammarström M. Obstetric risk factors for symptomatic prolapse: a population-based approach. Am J Obstet Gynecol. 2006;194(1):75-81.

127. Fritel X, Varnoux N, Zins M, Breart G, Ringa V. Symptomatic pelvic organ prolapse at midlife, quality of life, and risk factors. Obstet Gynecol. 2009;113(3):609-16. 128. Uma R, Libby G, Murphy DJ. Obstetric management of a woman's first delivery and the implications for pelvic floor surgery in later life. Bjog. 2005;112(8):1043-6. 129. Samuelsson EC, Victor FT, Tibblin G, Svärdsudd KF. Signs of genital prolapse in a Swedish population of women 20 to 59 years of age and possible related factors. Am $\mathrm{J}$ Obstet Gynecol. 1999;180(2 Pt 1):299-305.

130. Miedel A, Tegerstedt G, Mæhle-Schmidt M, Nyrén O, Hammarström M. Nonobstetric risk factors for symptomatic pelvic organ prolapse. Obstetrics \& Gynecology. 2009;113(5):1089-97.

131. Kudish BI, Iglesia CB, Sokol RJ, Cochrane B, Richter HE, Larson J, et al. Effect of weight change on natural history of pelvic organ prolapse. Obstetrics and gynecology. 2009;113(1):81.

132. Sharma A, Yuan L, Marshall RJ, Merrie AE, Bissett IP. Systematic review of the prevalence of faecal incontinence. Br J Surg. 2016;103(12):1589-97.

133. Solans-Domènech M, Sánchez E, Espuña-Pons M. Urinary and anal incontinence during pregnancy and postpartum: incidence, severity, and risk factors. Obstet Gynecol. 2010;115(3):618-28.

134. Guise JM, Morris C, Osterweil P, Li H, Rosenberg D, Greenlick M. Incidence of fecal incontinence after childbirth. Obstet Gynecol. 2007;109(2 Pt 1):281-8.

135. Eason E, Labrecque M, Marcoux S, Mondor M. Anal incontinence after childbirth. Cmaj. 2002;166(3):326-30. 
136. Nelson RL, Furner SE, Westercamp M, Farquhar C. Cesarean delivery for the prevention of anal incontinence. Cochrane Database Syst Rev. 2010;2010(2):Cd006756.

137. Oberwalder M, Connor J, Wexner SD. Meta-analysis to determine the incidence of obstetric anal sphincter damage. Br J Surg. 2003;90(11):1333-7.

138. Bharucha AE, Zinsmeister AR, Locke GR, Seide BM, McKeon K, Schleck CD, et al. Prevalence and burden of fecal incontinence: a population-based study in women. Gastroenterology. 2005;129(1):42-9.

139. Borello-France D, Burgio KL, Richter HE, Zyczynski H, Fitzgerald MP, Whitehead W, et al. Fecal and urinary incontinence in primiparous women. Obstet Gynecol. 2006;108(4):863-72.

140. Erekson EA, Sung VW, Myers DL. Effect of body mass index on the risk of anal incontinence and defecatory dysfunction in women. Am J Obstet Gynecol. 2008;198(5):596.e1-4.

141. Bharucha AE, Zinsmeister AR, Schleck CD, Melton LJ, 3rd. Bowel disturbances are the most important risk factors for late onset fecal incontinence: a population-based case-control study in women. Gastroenterology. 2010;139(5):1559-66. 142. Ditah I, Devaki P, Luma HN, Ditah C, Njei B, Jaiyeoba C, et al. Prevalence, trends, and risk factors for fecal incontinence in United States adults, 2005-2010. Clin Gastroenterol Hepatol. 2014;12(4):636-43.e1-2.

143. Leigh RJ, Turnberg LA. Faecal incontinence: the unvoiced symptom. Lancet. $1982 ; 1(8285): 1349-51$.

144. Hellström A, Hanson E, Hansson S, Hjälmäs K, Jodal U. Micturition habits and incontinence at age 17--reinvestigation ofa cohort studied at age 7. Br J Urol. 1995;76(2):2314. 
82 Pelvic Floor Dysfunction in Nulliparous Women

145. Swithinbank LV, Brookes ST, Shepherd AM, Abrams P. The natural history of urinary symptoms during adolescence. Br J Urol. 1998;81 Suppl 3:90-3.

146. Hirasing RA, van Leerdam FJ, Bolk-Bennink L, Janknegt RA. Enuresis nocturna in adults. Scand J Urol Nephrol. 1997;31(6):533-6.

147.

D'Ancona CA, Lopes MH, Faleiros-Martins AC, Lucio AC, Campos RM, Costa

JV. Childhood enuresis is a risk factor for bladder dysfunction in adult life? Neurourol Urodyn. 2012;31(5):634-6.

148. Gurbuz A, Karateke A, Kabaca C. Enuresis in childhood, and urinary and fecal incontinence in adult life: do they share a common cause? BJU Int. 2005;95(7):1058-62.

149. Yarnell JW, Voyle GJ, Sweetnam PM, Milbank J, Richards CJ, Stephenson TP. Factors associated with urinary incontinence in women. J Epidemiol Community Health. 1982;36(1):58-63.

150. Moore KH, Richmond DH, Parys BT. Sex distribution of adult idiopathic detrusor instability in relation to childhood bedwetting. Br J Urol. 1991;68(5):479-82. 151. Kuh D, Cardozo L, Hardy R. Urinary incontinence in middle aged women: childhood enuresis and other lifetime risk factors in a British prospective cohort. J Epidemiol Community Health. 1999;53(8):453-8.

152. Haylen BT, de Ridder D, Freeman RM, Swift SE, Berghmans B, Lee J, et al. An International Urogynecological Association (IUGA)/International Continence Society (ICS) joint report on the terminology for female pelvic floor dysfunction. Int Urogynecol J. 2010;21(1):5-26.

153. Austin PF, Bauer SB, Bower W, Chase J, Franco I, Hoebeke P, et al. The standardization of terminology of lower urinary tract function in children and adolescents: Update report from the standardization committee of the International Children's Continence Society. Neurourol Urodyn. 2016;35(4):471-81. 
154. Sandvik H, Seim A, Vanvik A, Hunskaar S. A severity index for epidemiological surveys of female urinary incontinence: comparison with 48-hour padweighing tests. Neurourol Urodyn. 2000;19(2):137-45.

155. Jorge JM, Wexner SD. Etiology and management of fecal incontinence. Dis Colon Rectum. 1993;36(1):77-97.

156. Thom DH, van den Eeden SK, Ragins AI, Wassel-Fyr C, Vittinghof E, Subak LL, et al. Differences in prevalence of urinary incontinence by race/ethnicity. J Urol. 2006;175(1):259-64.

157. Grodstein F, Fretts R, Lifford K, Resnick N, Curhan G. Association of age, race, and obstetric history with urinary symptoms among women in the Nurses' Health Study. Am J Obstet Gynecol. 2003;189(2):428-34.

158. Diokno AC, Brown MB, Brock BM, Herzog AR, Normolle DP. Clinical and cystometric characteristics of continent and incontinent noninstitutionalized elderly. J Urol. 1988;140(3):567-71.

159. Herzog AR, Fultz NH. Prevalence and incidence of urinary incontinence in community-dwelling populations. J Am Geriatr Soc. 1990;38(3):273-81.

160. Grimes DA, Schulz KF. An overview of clinical research: the lay of the land. Lancet. 2002;359(9300):57-61.

161. Rothman KJ, Sander Greenland, and Timothy L. Lash. Validity in Epidemiological studies. In: Rothman KJ, Sander Greenland, and Timothy L. Lash, editor. Modern Epidemiology. 3rd ed. Philadelphia: Lippincott Williams \& Wilkins; 2008. p. 128-47. 162. Asch DA, Jedrziewski MK, Christakis NA. Response rates to mail surveys published in medical journals. J Clin Epidemiol. 1997;50(10):1129-36. 
84 Pelvic Floor Dysfunction in Nulliparous Women

163. Sandvik H, Hunskaar S, Seim A, Hermstad R, Vanvik A, Bratt H. Validation of a severity index in female urinary incontinence and its implementation in an epidemiological survey. J Epidemiol Community Health. 1993;47(6):497-9.

164. Tegerstedt G, Miedel A, Maehle-Schmidt M, Nyren O, Hammarström M. A short-form questionnaire identified genital organ prolapse. J Clin Epidemiol. 2005;58(1):41-6. 165. Thom D. Variation in estimates of urinary incontinence prevalence in the community: effects of differences in definition, population characteristics, and study type. $\mathrm{J}$ Am Geriatr Soc. 1998;46(4):473-80.

166. Minassian VA, Stewart WF, Hirsch AG. Why do stress and urge incontinence co-occur much more often than expected? Int Urogynecol J Pelvic Floor Dysfunct. 2008;19(10):1429-40.

167. Sandvik H, Hunskaar S, Vanvik A, Bratt H, Seim A, Hermstad R. Diagnostic classification of female urinary incontinence: an epidemiological survey corrected for validity. J Clin Epidemiol. 1995;48(3):339-43.

168. Hannestad YS, Rortveit G, Hunskaar S. Help-seeking and associated factors in female urinary incontinence. The Norwegian EPINCONT Study. Epidemiology of Incontinence in the County of Nord-Trøndelag. Scand J Prim Health Care. 2002;20(2):102-7. 169. Bump RC, Mattiasson A, Bø K, Brubaker LP, DeLancey JO, Klarskov P, et al. The standardization of terminology of female pelvic organ prolapse and pelvic floor dysfunction. Am J Obstet Gynecol. 1996;175(1):10-7.

170. Kang HW, Jung HK, Kwon KJ, Song EM, Choi JY, Kim SE, et al. Prevalence and predictive factors of fecal incontinence. J Neurogastroenterol Motil. 2012;18(1):86-93. 171. Brown HW, Wexner SD, Segall MM, Brezoczky KL, Lukacz ES. Quality of life impact in women with accidental bowel leakage. Int J Clin Pract. 2012;66(11):1109-16. 
172. Aitola P, Lehto K, Fonsell R, Huhtala H. Prevalence of faecal incontinence in adults aged 30 years or more in general population. Colorectal Dis. 2010;12(7):687-91. 173. Zhang L, Zhu L, Xu T, Lang J, Li Z, Gong J, et al. A Population-based Survey of the Prevalence, Potential Risk Factors, and Symptom-specific Bother of Lower Urinary Tract Symptoms in Adult Chinese Women. Eur Urol. 2015;68(1):97-112.

174. McKinnie V, Swift SE, Wang W, Woodman P, O'Boyle A, Kahn M, et al. The effect of pregnancy and mode of delivery on the prevalence of urinary and fecal incontinence. Am J Obstet Gynecol. 2005;193(2):512-7; discussion 7-8.

175. Lukacz ES, Lawrence JM, Contreras R, Nager CW, Luber KM. Parity, mode of delivery, and pelvic floor disorders. Obstet Gynecol. 2006;107(6):1253-60.

176. O'Halloran T, Bell RJ, Robinson PJ, Davis SR. Urinary incontinence in young nulligravid women: a cross-sectional analysis. Ann Intern Med. 2012;157(2):87-93.

177. Bardino M, Di Martino M, Ricci E, Parazzini F. Frequency and Determinants of Urinary Incontinence in Adolescent and Young Nulliparous Women. J Pediatr Adolesc Gynecol. 2015;28(6):462-70.

178. Simeonova Z, Milsom I, Kullendorff AM, Molander U, Bengtsson C. The prevalence of urinary incontinence and its influence on the quality of life in women from an urban Swedish population. Acta Obstet Gynecol Scand. 1999;78(6):546-51.

179. Elving LB, Foldspang A, Lam GW, Mommsen S. Descriptive epidemiology of urinary incontinence in 3,100 women age 30-59. Scand J Urol Nephrol Suppl. 1989;125:3743.

180. Cooper J, Annappa M, Dracocardos D, Cooper W, Muller S, Mallen C. Prevalence of genital prolapse symptoms in primary care: a cross-sectional survey. Int Urogynecol J. 2015;26(4):505-10. 
86 Pelvic Floor Dysfunction in Nulliparous Women

181. Quiroz LH, White DE, Juarez D, Shobeiri SA. Age effects on pelvic floor symptoms in a cohort of nulliparous patients. Female Pelvic Med Reconstr Surg. 2012;18(6):325-8.

182. Sze EH, Hobbs G. Relation between vaginal birth and pelvic organ prolapse. Acta Obstet Gynecol Scand. 2009;88(2):200-3.

183. Swift SE. The distribution of pelvic organ support in a population of female subjects seen for routine gynecologic health care. Am J Obstet Gynecol. 2000;183(2):277-85. 184. Norton PA, Baker JE, Sharp HC, Warenski JC. Genitourinary prolapse and joint hypermobility in women. Obstet Gynecol. 1995;85(2):225-8.

185. Lo TS, Jaili S, Uy-Patrimonio MC, Karim NB, Ibrahim R. Transvaginal management of severe pelvic organ prolapse in nulliparous women. J Obstet Gynaecol Res. 2017;43(3):543-50.

186. Wan L, Liu X. Delayed-onset advanced pelvic organ prolapse after spinal cord injury in a young, nulliparous woman. Int Urogynecol J. 2016;27(5):825-7.

187. Dietz HP, Clarke B. Prevalence of rectocele in young nulliparous women. Aust N Z J Obstet Gynaecol. 2005;45(5):391-4.

188. $\quad$ http://www.gynop.org/english/english.htm

189. Ellerkmann RM, Cundiff GW, Melick CF, Nihira MA, Leffler K, Bent AE. Correlation of symptoms with location and severity of pelvic organ prolapse. Am J Obstet Gynecol. 2001;185(6):1332-7; discussion 7-8.

190. Swift SE, Tate SB, Nicholas J. Correlation of symptoms with degree of pelvic organ support in a general population of women: what is pelvic organ prolapse? Am J Obstet Gynecol. 2003;189(2):372-7; discussion 7-9. 
191.

Tan JS, Lukacz ES, Menefee SA, Powell CR, Nager CW. Predictive value of prolapse symptoms: a large database study. Int Urogynecol J Pelvic Floor Dysfunct. 2005;16(3):203-9; discussion 9.

192. Leijonhufvud A, Lundholm C, Cnattingius S, Granath F, Andolf E, Altman D. Risks of stress urinary incontinence and pelvic organ prolapse surgery in relation to mode of childbirth. Am J Obstet Gynecol. 2011;204(1):70.e1-7.

193. Thomas V, Shek KL, Guzmán Rojas R, Dietz HP. Temporal latency between pelvic floor trauma and presentation for prolapse surgery: a retrospective observational study. International Urogynecology Journal. 2015;26(8):1185-9.

194. DELANCEY JOL. Anatomy and Biomechanics of Genital Prolapse. Clinical Obstetrics and Gynecology. 1993;36(4):897-909.

195. Handa VL, Blomquist JL, Roem J, Muňoz A. Longitudinal study of quantitative changes in pelvic organ support among parous women. Am J Obstet Gynecol. 2018;218(3):320.e1-.e7.

196. Ransohoff DF, Feinstein AR. Problems of spectrum and bias in evaluating the efficacy of diagnostic tests. N Engl J Med. 1978;299(17):926-30.

197. Weber AM, Abrams P, Brubaker L, Cundiff G, Davis G, Dmochowski RR, et al. The standardization of terminology for researchers in female pelvic floor disorders. Int Urogynecol J Pelvic Floor Dysfunct. 2001;12(3):178-86.

198. Barber MD, Neubauer NL, Klein-Olarte V. Can we screen for pelvic organ prolapse without a physical examination in epidemiologic studies? Am J Obstet Gynecol. 2006;195(4):942-8.

199. Foldspang A, Mommsen S. Adult female urinary incontinence and childhood bedwetting. J Urol. 1994;152(1):85-8. 
88 Pelvic Floor Dysfunction in Nulliparous Women

200. Fitzgerald MP, Thom DH, Wassel-Fyr C, Subak L, Brubaker L, Van Den Eeden

SK, et al. Childhood urinary symptoms predict adult overactive bladder symptoms. J Urol. 2006;175(3 Pt 1):989-93.

201. Rommen K, Schei B, Rydning A, A HS, Morkved S. Prevalence of anal incontinence among Norwegian women: a cross-sectional study. BMJ Open. 2012;2(4).

202. Svare JA, Hansen BB, Lose G. Prevalence of anal incontinence during pregnancy and 1 year after delivery in a cohort of primiparous women and a control group of nulliparous women. Acta Obstet Gynecol Scand. 2016;95(8):920-5.

203. van Meegdenburg MM, Trzpis M, Broens PM. Fecal incontinence and parity in the Dutch population: A cross-sectional analysis. United European Gastroenterol J. 2018;6(5):781-90.

204. Varma MG, Brown JS, Creasman JM, Thom DH, Van Den Eeden SK, Beattie MS, et al. Fecal incontinence in females older than aged 40 years: who is at risk? Dis Colon Rectum. 2006;49(6):841-51.

205. Robinson BL, Matthews CA, Palsson OS, Geller E, Turner M, Parnell B, et al. Obstetric sphincter injury interacts with diarrhea and urgency to increase the risk of fecal incontinence in women with irritable bowel syndrome. Female Pelvic Med Reconstr Surg. $2013 ; 19(1): 40-5$.

206. Santoro A, Wieczorek A, Sultan A. Pelvic floor disorders : a multidisciplinary textbook2021.

207. Rockwood TH, Church JM, Fleshman JW, Kane RL, Mavrantonis C, Thorson AG, et al. Patient and surgeon ranking of the severity of symptoms associated with fecal incontinence: the fecal incontinence severity index. Dis Colon Rectum. 1999;42(12):1525-32. 
208. Kalantar JS, Howell S, Talley NJ. Prevalence of faecal incontinence and associated risk factors; an underdiagnosed problem in the Australian community? Med J Aust. 2002;176(2):54-7.

209. Whitehead WE, Borrud L, Goode PS, Meikle S, Mueller ER, Tuteja A, et al. Fecal incontinence in US adults: epidemiology and risk factors. Gastroenterology. 2009; 137(2):512-7, 7.e1-2.

210. Lovell RM, Ford AC. Global prevalence of and risk factors for irritable bowel syndrome: a meta-analysis. Clin Gastroenterol Hepatol. 2012;10(7):712-21.e4.

211. Sperber AD, Dumitrascu D, Fukudo S, Gerson C, Ghoshal UC, Gwee KA, et al. The global prevalence of IBS in adults remains elusive due to the heterogeneity of studies: a Rome Foundation working team literature review. Gut. 2017;66(6):1075-82.

212. Drossman DA, Li Z, Andruzzi E, Temple RD, Talley NJ, Thompson WG, et al. U.S. householder survey of functional gastrointestinal disorders. Prevalence, sociodemography, and health impact. Dig Dis Sci. 1993;38(9):1569-80.

213. Townsend DC, Carrington EV, Grossi U, Burgell RE, Wong JY, Knowles CH, et al. Pathophysiology of fecal incontinence differs between men and women: a case-matched study in 200 patients. Neurogastroenterol Motil. 2016;28(10):1580-8.

214. Simrén M, Palsson OS, Heymen S, Bajor A, Törnblom H, Whitehead WE. Fecal incontinence in irritable bowel syndrome: Prevalence and associated factors in Swedish and American patients. Neurogastroenterol Motil. 2017;29(2).

215. Longstreth GF, Wolde-Tsadik G. Irritable bowel-type symptoms in HMO examinees. Prevalence, demographics, and clinical correlates. Dig Dis Sci. 1993;38(9):15819.

216. Longstreth GF, Thompson WG, Chey WD, Houghton LA, Mearin F, Spiller RC. Functional bowel disorders. Gastroenterology. 2006;130(5):1480-91. 
90 Pelvic Floor Dysfunction in Nulliparous Women

217. Gorina Y, Schappert S, Bercovitz A, Elgaddal N, Kramarow E. Prevalence of incontinence among older americans. Vital Health Stat 3. 2014(36):1-33.

218. Richter HE, Burgio KL, Clements RH, Goode PS, Redden DT, Varner RE.

Urinary and anal incontinence in morbidly obese women considering weight loss surgery.

Obstet Gynecol. 2005;106(6):1272-7.

219. Walter S, Hallböök O, Gotthard R, Bergmark M, Sjödahl R. A population-based study on bowel habits in a Swedish community: prevalence of faecal incontinence and constipation. Scand J Gastroenterol. 2002;37(8):911-6.

220. Ng KS, Nassar N, Hamd K, Nagarajah A, Gladman MA. Prevalence of functional bowel disorders and faecal incontinence: an Australian primary care survey. Colorectal Dis. 2015;17(2):150-9.

221. Rothman KJ, Greenland S, Lash TL. Design strategies to improve study accuracy. Modern epidemiology. 2008;3:168-82. 


\section{Appendix}

Appendix 1: Questionnaire

\begin{tabular}{|c|c|c|}
\hline \multicolumn{3}{|c|}{ Questionnaire } \\
\hline Q1 & How tall are you? & $\mathrm{cm}$ \\
\hline Q2 & How much do you weigh? & $\mathrm{kg}$ \\
\hline Q3 & Have you given birth? & $\begin{array}{l}\text { Yes } \\
\text { If so, how many children have } \\
\text { you had? } \\
\text { No, I have not given birth }\end{array}$ \\
\hline Q4 & Do you still have menstrual periods? & $\begin{array}{l}\text { Yes/No } \\
\text { If yes, go to Q6 }\end{array}$ \\
\hline Q5 & If you have no menstrual periods, what is the cause? & \\
\hline $\mathrm{a}$ & Are you pregnant? & Yes/No \\
\hline $\mathrm{b}$ & Has your uterus been removed? & Yes/No \\
\hline $\mathrm{c}$ & Do you use an intrauterine hormone device? & Yes/No \\
\hline $\mathrm{d}$ & Are you in the menopause? & Yes/No \\
\hline
\end{tabular}


92 Pelvic Floor Dysfunction in Nulliparous Women

\begin{tabular}{|c|c|c|}
\hline e & Do you use estrogen? & Yes/No \\
\hline f. & Other causes? & Yes/No \\
\hline & SYMPTOMS FROM THE URINARY TRACT & \\
\hline Q6 & $\begin{array}{l}\text { How many times do you urinate during the daytime, } \\
\text { on average? }\end{array}$ & \\
\hline Q7 & Do you have to urinate during the night? & $\begin{array}{l}\text { Yes } \\
\text { If yes, how many times? } \\
\text { No }\end{array}$ \\
\hline Q8 & $\begin{array}{l}\text { Do you have urinary urgency with a sudden and } \\
\text { strong urge to void, which is hard to postpone? }\end{array}$ & $\begin{array}{l}\text { Yes } \\
\text { No, if no go to Q10 }\end{array}$ \\
\hline Q9 & How does your urinary urgency affect you? & $\begin{array}{l}\text { No problem } \\
\text { A minor nuisance } \\
\text { Some bother } \\
\text { Much bother } \\
\text { A major problem }\end{array}$ \\
\hline Q10 & Do you take any medication for urinary urgency? & Yes/No \\
\hline
\end{tabular}




\begin{tabular}{|c|c|c|}
\hline Q11 & $\begin{array}{l}\text { Were you a bed wetter during childhood, } \\
\text { (involuntary loss of urine whilst sleeping)? }\end{array}$ & $\begin{array}{l}\text { Yes, } \\
\text { If yes at what age did it stop? } \\
\text { No }\end{array}$ \\
\hline Q12 & Do you have involuntary loss of urine? & $\begin{array}{l}\text { Yes/No } \\
\text { If no, go to Q21 }\end{array}$ \\
\hline Q13 & How often do you have involuntary loss of urine? & $\begin{array}{l}\text { Less than once a month } \\
\text { Once or more per month } \\
\text { Once or more per week } \\
\text { Every day and/or night }\end{array}$ \\
\hline Q14 & How much urine do you leak each time? & $\begin{array}{l}\text {-a few drops } \\
\text {-small amounts } \\
\text {-large amounts }\end{array}$ \\
\hline Q15 & $\begin{array}{l}\text { Do you have involuntary loss of urine in connection } \\
\text { with coughing, sneezing, laughing, or lifting heavy } \\
\text { items? }\end{array}$ & Yes/No \\
\hline Q16 & $\begin{array}{l}\text { Do you have involuntary loss of urine in connection } \\
\text { with a sudden and strong urge to void? }\end{array}$ & Yes/No \\
\hline Q17 & $\begin{array}{l}\text { For how long have you had involuntary loss of } \\
\text { urine? }\end{array}$ & $\begin{array}{l}0-5 \text { years } \\
5-10 \text { years } \\
\text { More than } 10 \text { years }\end{array}$ \\
\hline
\end{tabular}


94 Pelvic Floor Dysfunction in Nulliparous Women

\begin{tabular}{|c|c|c|}
\hline Q18 & $\begin{array}{l}\text { Have you consulted a doctor because of involuntary } \\
\text { loss of urine? }\end{array}$ & Yes/No \\
\hline Q19 & How does your urinary leakage affect you? & $\begin{array}{l}\text { No problem } \\
\text { A minor nuisance } \\
\text { Some bother } \\
\text { Much bother } \\
\text { A major problem }\end{array}$ \\
\hline Q20 & $\begin{array}{l}\text { If you have given birth- did you have urinary leakage } \\
\text { even before the first pregnancy? }\end{array}$ & Yes/No \\
\hline Q21 & $\begin{array}{l}\text { Have you had any surgery for a urinary } \\
\text { incontinence? }\end{array}$ & Yes/No \\
\hline Q22 & $\begin{array}{l}\text { Do you take any medication for urinary } \\
\text { incontinence? }\end{array}$ & Yes/No \\
\hline Q23 & Has your mother suffered from urinary leakage? & Yes/No/Do not know \\
\hline & SYMPTOMS FROM THE VAGINA & \\
\hline Q24 & $\begin{array}{l}\text { Do you have a sensation of tissue protrusion (a } \\
\text { vaginal bulge) from your vagina? }\end{array}$ & $\begin{array}{l}\text { Often } \\
\text { Sometimes } \\
\text { Infrequently } \\
\text { Never }\end{array}$ \\
\hline
\end{tabular}




\begin{tabular}{|c|c|c|}
\hline Q25 & $\begin{array}{l}\text { Do you suffer from a chafing/a rubbing feeling in } \\
\text { your vagina/vulva? }\end{array}$ & $\begin{array}{l}\text { Often } \\
\text { Sometimes } \\
\text { Infrequently } \\
\text { Never }\end{array}$ \\
\hline Q26 & $\begin{array}{l}\text { Do you have to lift the front vaginal wall to start or } \\
\text { complete voiding? }\end{array}$ & $\begin{array}{l}\text { Often } \\
\text { Sometimes } \\
\text { Infrequently } \\
\text { Never }\end{array}$ \\
\hline & $\begin{array}{l}\text { If you have no discomforts from your vagina, } \\
\text { proceed to Q29. }\end{array}$ & \\
\hline Q27 & $\begin{array}{l}\text { Are your symptoms worse during straining, for } \\
\text { example, during heavy lifting? }\end{array}$ & $\begin{array}{l}\text { Unchanged } \\
\text { Better } \\
\text { Worse }\end{array}$ \\
\hline Q28 & How do these vaginal symptoms affect you? & $\begin{array}{l}\text { No problem } \\
\text { A minor nuisance } \\
\text { Some bother } \\
\text { Much bother } \\
\text { A major problem }\end{array}$ \\
\hline Q29 & Have you received (any) treatment for a prolapse? & Yes/No \\
\hline Q30 & Have you had any surgery for a prolapse? & Yes/No \\
\hline Q31 & Has your mother suffered from prolapse? & Yes/No/Do not know \\
\hline
\end{tabular}




\begin{tabular}{|c|c|c|}
\hline & SYMPTOMS FROM YOUR BACK PASSAGE & \\
\hline Q32 & Do you leak solid faeces involuntarily? & $\begin{array}{l}\text { Never } \\
\text { Less than once a month } \\
\text { Several times a month but less } \\
\text { than once a week } \\
\text { Once a week or more } \\
\text { Once a day or more }\end{array}$ \\
\hline Q33 & Do you leak liquid faeces involuntarily? & $\begin{array}{l}\text { Never } \\
\text { Less than once a month } \\
\text { Several times a month but less } \\
\text { than once a week } \\
\text { Once a week or more } \\
\text { Once a day or more }\end{array}$ \\
\hline Q34 & Do you leak flatus/gas involuntarily? & $\begin{array}{l}\text { Never } \\
\text { Less than once a month } \\
\text { Several times a month but less } \\
\text { than once a week } \\
\text { Once a week or more } \\
\text { Once a day or more }\end{array}$ \\
\hline Q35 & $\begin{array}{l}\text { Do you use a protective product/pad because of } \\
\text { involuntary leakage from the back passage? }\end{array}$ & $\begin{array}{l}\text { Never } \\
\text { Less than once a month } \\
\text { Several times a month but less } \\
\text { than once a week }\end{array}$ \\
\hline
\end{tabular}




\begin{tabular}{|c|c|c|}
\hline & & $\begin{array}{l}\text { Once a week or more } \\
\text { Once a day or more }\end{array}$ \\
\hline Q36 & $\begin{array}{l}\text { Is your daily life style affected by involuntary } \\
\text { leakage from your back passage? }\end{array}$ & $\begin{array}{l}\text { Never } \\
\text { Less than once a month } \\
\text { Several times a month but less } \\
\text { than once a week } \\
\text { Once a week or more } \\
\text { Once a day or more }\end{array}$ \\
\hline Q37 & How do your bowel symptoms affect you? & $\begin{array}{l}\text { No problem } \\
\text { A minor nuisance } \\
\text { Some bother } \\
\text { Much bother } \\
\text { A major problem }\end{array}$ \\
\hline Q38 & $\begin{array}{l}\text { Have you received (any) treatment for leakage of } \\
\text { flatus/gas or faeces? }\end{array}$ & Yes/No \\
\hline Q39 & $\begin{array}{l}\text { Has your mother suffered from leakage of flatus/gas } \\
\text { or faeces? }\end{array}$ & Yes/No/Do not know \\
\hline Q40 & $\begin{array}{l}\text { On the lines below there is room for your own } \\
\text { comments regarding this questionnaire }\end{array}$ & $\ldots$ \\
\hline
\end{tabular}


98 Pelvic Floor Dysfunction in Nulliparous Women

Appendix 2: Characteristics of responders versus non-responders

\begin{tabular}{|c|c|c|c|}
\hline \multirow[t]{2}{*}{ Variables } & \multirow[t]{2}{*}{ Subgroup } & $\begin{array}{l}\text { Responders } \\
\mathrm{n}=10,187(52.2 \%)\end{array}$ & $\begin{array}{l}\text { Non-responders } \\
\mathrm{n}=9340(47.8 \%)\end{array}$ \\
\hline & & \multicolumn{2}{|c|}{$\mathrm{n}(\%)$} \\
\hline Age group & $\begin{array}{l}25-34 \\
35-44 \\
45-54 \\
55-64\end{array}$ & $\begin{array}{l}3570(44.7) \\
2838(47.4) \\
1644(54.8) \\
1871(62.4)\end{array}$ & $\begin{array}{l}4423(55.3) \\
3153(52.6) \\
1354(45.2) \\
1128(37.6)\end{array}$ \\
\hline $\begin{array}{l}\text { Country } \\
\text { of birth }\end{array}$ & $\begin{array}{l}\text { Sweden } \\
\text { Abroad }\end{array}$ & $\begin{array}{l}8146(54.0) \\
1777(36.3)\end{array}$ & $\begin{array}{l}6934(46.0) \\
3124(63.7)\end{array}$ \\
\hline Citizenship & $\begin{array}{l}\text { Swedish } \\
\text { Foreign }\end{array}$ & $\begin{array}{l}9042(52.4) \\
881(32.2)\end{array}$ & $\begin{array}{l}8200(47.6) \\
1858(67.8)\end{array}$ \\
\hline Marital status & $\begin{array}{l}\text { Married } \\
\text { Unmarried } \\
\text { Divorced } \\
\text { Widowed }\end{array}$ & $\begin{array}{l}2225(54.7) \\
6994(48.8) \\
622(44.2) \\
82(50.6)\end{array}$ & $\begin{array}{l}1843(45.3) \\
7350(51.2) \\
785(55.8) \\
80(49.4)\end{array}$ \\
\hline Income (SEK) & $\begin{array}{l}\text { No income } \\
1-124,999 \\
125,000-199,000 \\
200,000-279,999 \\
280,000-369,999 \\
\geq 370,000\end{array}$ & $\begin{array}{l}710(29.8) \\
1822(43.7) \\
1233(48.6) \\
1870(49.7) \\
2484(57.7) \\
1804(64.0)\end{array}$ & $\begin{array}{l}1675(70.0) \\
2350(56.3) \\
1305(51.4) \\
1889(50.3) \\
1824(42.3) \\
1015(36.0)\end{array}$ \\
\hline Communities & $\begin{array}{l}\text { Large city } \\
\text { Suburb to a large city } \\
\text { Medium-sized town } \\
\text { Suburb to a medium-sized town } \\
\text { Commuting municipality } \\
\text { Tourism municipality } \\
\text { Goods-producing municipality } \\
\text { Sparsely populated municipality } \\
\text { Densely populated region } \\
\text { Sparsely populated region }\end{array}$ & $\begin{array}{l}3120(51.0) \\
1345(45.6) \\
2844(50.1) \\
216(47.5) \\
516(47.8) \\
234(51.0) \\
598(49.5) \\
120(48.8) \\
671(51.4) \\
259(54.3)\end{array}$ & $\begin{array}{l}3001(49.0) \\
1606(54.4) \\
2835(49.9) \\
239(52.5) \\
564(52.2) \\
225(49.0) \\
609(50.5) \\
126(51.2) \\
635(48.6) \\
218(45.7)\end{array}$ \\
\hline Education & $\begin{array}{l}\text { Unknown } \\
\text { Compulsory school } \\
\text { High school } \\
\text { Upper secondary, <3 y } \\
\text { Upper secondary, } \geq 3 \text { y }\end{array}$ & $\begin{array}{l}248(23.1) \\
619(33.6) \\
3310(47.0) \\
1931(54.0) \\
3815(59.1)\end{array}$ & $\begin{array}{l}824(76.9) \\
1225(66.4) \\
3729(53.0) \\
1645(46.0) \\
2635(40.9)\end{array}$ \\
\hline
\end{tabular}


Al-Mukhtar Othman 99 
